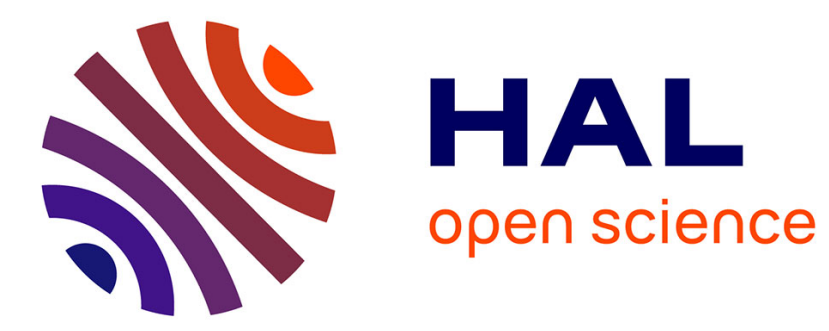

\title{
Thermal oxidation of aromatic epoxy-diamine networks
}

Justine Delozanne, Nancy Desgardin, Nicolas Cuvillier, Emmanuel Richaud

\section{To cite this version:}

Justine Delozanne, Nancy Desgardin, Nicolas Cuvillier, Emmanuel Richaud. Thermal oxidation of aromatic epoxy-diamine networks. Polymer Degradation and Stability, 2019, 166, pp.174-187. 10.1016/j.polymdegradstab.2019.05.030 . hal-02163906

\section{HAL Id: hal-02163906 https://hal.science/hal-02163906}

Submitted on 24 Jun 2019

HAL is a multi-disciplinary open access archive for the deposit and dissemination of scientific research documents, whether they are published or not. The documents may come from teaching and research institutions in France or abroad, or from public or private research centers.
L'archive ouverte pluridisciplinaire HAL, est destinée au dépôt et à la diffusion de documents scientifiques de niveau recherche, publiés ou non, émanant des établissements d'enseignement et de recherche français ou étrangers, des laboratoires publics ou privés. 


\title{
Thermal oxidation of aromatic epoxy-diamine networks
}

\author{
Justine Delozanne a, b, Nancy Desgardin ${ }^{\text {b }}$, Nicolas Cuvillier ${ }^{\text {b }}$, Emmanuel Richaud ${ }^{\text {a, * }}$ \\ a Laboratoire PIMM, Arts et Metiers ParisTech, CNRS, Cnam, 151 boulevard de l'Hôpital, 75013, Paris, France \\ b SAFRAN Composites, 33 avenue de la Gare, 91760, Itteville, France
}

Keywords

Epoxy-diamine

Thermal oxidation

FTIR

\begin{abstract}
A B S T R A C T
The thermal oxidation of DGEBA-DDS (bisphenol A diglycidyl ether $+4,4^{\prime}$-diaminodiphenyl sulfone) and TGMDA-DDS (4,4'-methylenebis(N,N-diglycidylaniline) + 4,4'-diaminodiphenyl sulfone) was performed at 80,120 , and $200{ }^{\circ} \mathrm{C}$ and was monitored by FTIR. Oxidation was shown to generate amides and carbonyls. Comparisons were done with model systems displaying some common reactive groups, which highlighted the predominating role of methylene in $\alpha$ position of ether in DGEBA-DDS and methylene in $\alpha$ position of nitrogen hold by TGMDA in TGMDA-DDS. The participation of $\mathrm{CH}_{2}$ in $\alpha$ position of DDS hardener group seems to depend on the temperature and decrease when lowering it. The oxidation of such complex systems must hence be described by a co-oxidation model where each kind of reactive sites is described by its own set of kinetic constants.
\end{abstract}

\section{Introduction}

Thermal oxidation of epoxies is documented to induce chain scissions [1,2] and later volatile compounds [3,4]. The subsequent mass loss results in the appearance of cracks favoring the access of oxygen to deeper layers [5]. In the field of epoxy adhesives used at high temperatures, mass loss seems correlated with the drop of adhesive strength [6]. In a recent work on titanium/epoxy/titanium bonded assemblies, microscopic analyses lead us to propose that thermal oxidation induced a cohesive failure of the epoxy-adhesive [7]. Such mechanisms of embrittlement seem to originate from the depletion of the $\beta$ relaxation associated to plasticity and toughness in epoxy/diamine networks [8] i.e. from the radical attack of hydroxypropylethers groups.

It is hence crucial to understand the reactivity of hydroxypropylethers for predicting lifetime of epoxy networks. However, one of the main difficulties is that epoxy-diamine networks are insoluble and can only be analyzed by FTIR at low conversion degrees of oxidation. Another difficulty is linked to the structural complexity of epoxy-diamine networks family, which is actually constituted by a wide number of prepolymer hardener pairs, where several sites are likely to participate to the oxidation process [9-11]. The glass transition of networks ranges from less than $100^{\circ} \mathrm{C}$ to more than $200^{\circ} \mathrm{C}[2,12,13]$ so that a supplementary level of complexity linked to the effect of macromolecular mobility might complicate the comparison of data obtained in glassy state or

\footnotetext{
* Corresponding author.

E-mail address: emmanuel.richaud@ensam.eu (E. Richaud).
}

rubbery one.

DGEBA-DDS and TGMDA-DDS appear as ideal cases since hydroxypropylethers are possibly the only reactive site. Moreover, their oxidation at temperatures below $200^{\circ} \mathrm{C}$ can be compared only in terms of reactivity since both networks are in glassy state (and above their $\beta$ relaxation) in this temperature range. However, few papers deal with their oxidation at molecular level. Most of them address either the case of high temperature thermal degradation of TGMDA-DDS $\left(\mathrm{T}>200^{\circ} \mathrm{C}\right.$ where mechanisms would be initiated by water elimination in secondary alcohol groups i.e. $-\mathrm{O}-\mathrm{CH}_{2}-\mathrm{CHOH}-$ $\mathrm{CH}_{2}-\mathrm{N}<\rightarrow-\mathrm{O}-\mathrm{CH}_{2}-\mathrm{CH}=\mathrm{CH}_{2}-\mathrm{N}<+\mathrm{H}_{2} \mathrm{O}$ [14-16]) or photooxidation of DGEBA-DDS $[17,18]$ at moderate temperature. Determining the thermal oxidation mechanism of aromatic networks in the maximal use temperatures of airplanes $\left(\sim 120^{\circ} \mathrm{C}\right)$ remains thus for us an open task.

The aim of this paper is therefore to compare the reactivity of DGEBA-DDS and TGMDA-DDS in thermal degradation at moderate temperature and understand the nature of reactive sites, so as to answer to the following questions:

- which sites are the more oxidizable in hydroxypropylethers?

- what is the most probable mechanism (in terms of degradation kinetics)?

- what is the role of chemical environment on the oxidation of hydroxypropylethers?

Since all oxidation products appear in a relatively narrow wavenumber range, we will also study the degradation of model systems with common reactive sites so as to better understand the 
degradation of TGMDA-DDS and DGEBA-DDS.

The answers of those questions will help to conclude on the reliability of the hypothesis according to which the thermal oxidation of aromatic epoxy networks can be modeled by considering the isoreactivity of each site present in the network [19-21].

\section{Experimental}

\subsection{Materials}

Two epoxy-diamine systems were based on chemicals presented in Fig. 1:

- DGEBA (DER 330, CAS 25058-38-6) supplied by Dow $\left(\mathrm{M}=340 \mathrm{~g} \mathrm{~mol}^{-1}\right)$

- TGMDA (ARALDITE MY721 CH, CAS 28768-32-3) supplied by Huntsman $\left(\mathrm{M}=422 \mathrm{~g} \mathrm{~mol}^{-1}\right)$

- DDS (ARADUR 976-1 NL, CAS 80-08-0) supplied by Huntsman $\left(\mathrm{M}=248 \mathrm{~g} \mathrm{~mol}^{-1}\right)$

Some comparisons were performed with DGEBA and TGMDA in their unreacted form.

A linear phenoxy resin (denoted by PKHJ - CAS: 25068-38-6 - ref 181196-250G from Sigma Aldrich) was also studied. This latter was supplied as pellets which were pressed at $200^{\circ} \mathrm{C}$ during $60 \mathrm{~s}$ using a Gibritte press so as to obtain about $35 \mu \mathrm{m}$ thin films.

The in-situ DSC (Q10 apparatus - TA Instruments) curing of TGMDA-DDS and DGEBA-DDS was studied by heating samples from $-70^{\circ} \mathrm{C}$ to $300^{\circ} \mathrm{C}$ at a $10^{\circ} \mathrm{C} \mathrm{min}^{-1}$ rate under $50 \mathrm{ml} \mathrm{min}{ }^{-1}$ nitrogen flow (see Fig. 2 for TGMDA-DDS). The measured characteristics (temperature of maximal heat release $\mathrm{T}_{\max }$, onset temperature $\mathrm{T}_{\text {onset, }}$, curing enthalpy $\Delta \mathrm{H}$ ) are gathered in Table 1 .

DGEBA-DDS and TGMDA-DDS were hence cured at $150{ }^{\circ} \mathrm{C}$ during $3 \mathrm{~h}$ under vacuum so as to get about $30 \mu \mathrm{m}$ thick films in which the Diffusion Limited Oxidation effects [22] can be neglected. TGMDA-DDS and DGEBA-DDS were then post cured respectively $1 \mathrm{~h}$ at $180^{\circ} \mathrm{C}$ and $1 \mathrm{~h}$ at $200^{\circ} \mathrm{C}$ under nitrogen (so as to limit the preoxidation). The degree of cure (very close to $100 \%$ ) was checked from the disappearance of any residual exotherm.

\subsection{Exposure conditions}

Thermal ageing of $35 \mu \mathrm{m}$ films was performed in ventilated<smiles>CN(CC1CO1)c1ccc(Cc2ccc(N(C)CC3CO3)cc2)cc1</smiles><smiles>COc1ccc(C(C)(C)c2ccc(OCC3CO3)cc2)cc1</smiles><smiles>Nc1ccc(S(=O)(=O)c2ccc(N)cc2)cc1</smiles>

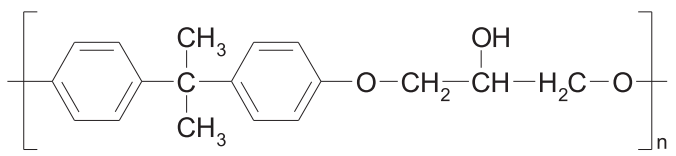

Fig. 1. Structure of monomers and model systems under study: TGMDA (a), DGEBA (b), DDS (c), PKHJ (d)

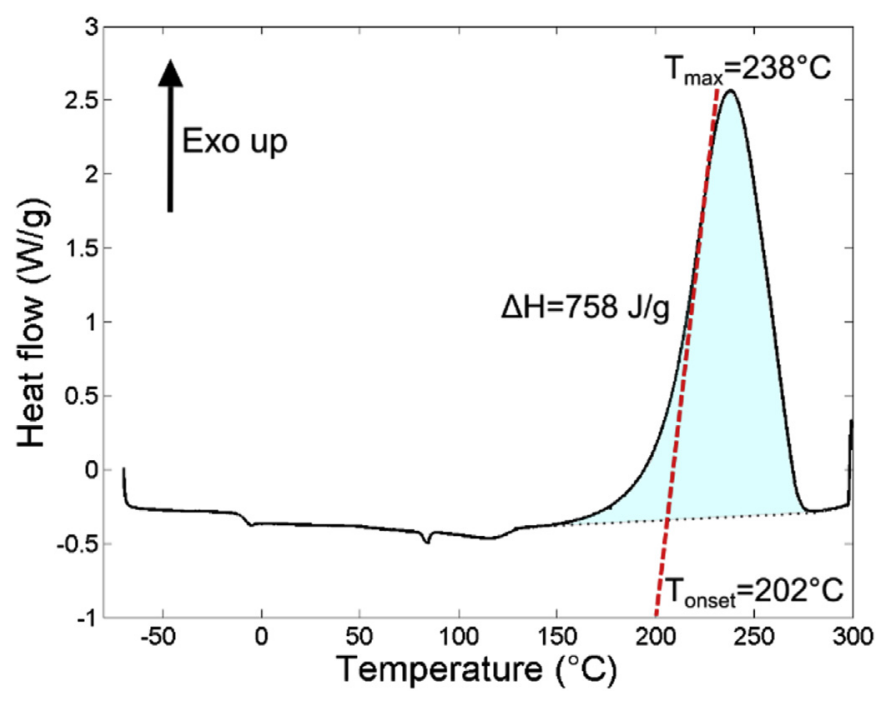

Fig. 2. Curing thermogram of TGMDA-DDS.

ovens (System Climatic Service) at 80,120 , and $200^{\circ} \mathrm{C}$ under air.

\subsection{Characterization}

FTIR spectroscopy was used in transmission mode on thin DGEBA-DDS, TGMDA-DDS and PKHJ films using a Frontier apparatus (PerkinElmer) by averaging 16 scans in the $400-4000 \mathrm{~cm}^{-1}$ wavenumber range at a $4 \mathrm{~cm}^{-1}$ resolution. Absorbances were measured by subtracting the baseline value and were then converted in concentration using Beer-Lambert law:

$A_{\lambda}=\varepsilon_{\lambda} \times l \times c$

where $A_{\lambda}$ is the absorbance, 1 the thickness of the film (expressed in $\mathrm{cm}$ ), $\mathrm{c}$ the concentration (in mol $\mathrm{l}^{-1}$ ) and $\varepsilon_{\lambda}$ the molar absorptivity at the considered wavenumber (in $1 \mathrm{~mol}^{-1} \mathrm{~cm}^{-1}$ ). Concentrations of oxidation products were thus assessed using molar absorptivity values equal to $500 \mathrm{l} \mathrm{mol}^{-1} \mathrm{~cm}^{-1}$ for carbonyls at $1765 \mathrm{~cm}^{-1}$ in PKHJ (estimated from phenyl acetate - see Appendix 1), $6801 \mathrm{~mol}^{-1} \mathrm{~cm}^{-1}$ for carboxylic acids at $1730 \mathrm{~cm}^{-1}$ in TGMDA-DDS [23] and $470 \mathrm{lmol}^{-1} \mathrm{~cm}^{-1}$ for amides at $1675 \mathrm{~cm}^{-1}$ [10] (NB: the nature of the products will be justified later).

Some comparisons were performed with the oxidation of TGMDA and DGEBA monomers. A single drop of monomer solution in THF was casted on $\mathrm{KBr}$ plates and evaporated. The thickness was assessed from the aryl absorbance $\left(1614 \mathrm{~cm}^{-1}\right)$ with $\varepsilon=3201 \mathrm{~mol}^{-1} \mathrm{~cm}^{-1}$ for TGMDA (this value was estimated from a single calibration in a $12 \mu \mathrm{m}$ thin cell).

The analysis of wavelength region ranging from 1600 to $1800 \mathrm{~cm}^{-1}$ is tricky because of the overlapping of several absorptions due to various stable products. The broad bands were hence deconvoluted for a better scrutiny. The deconvoluted peaks were supposed to be gaussian with maximal absorption, wavenumber of maximal absorbance and width at middle height as fitting parameters.

\section{Results}

3.1. Formation of stable products epoxy amine networks and their model systems

\subsubsection{DGEBA-DDS}

Spectra of DGEBA-DDS samples after varying exposure times at $120^{\circ} \mathrm{C}$ are overlapped in Fig. 3 which calls for the following comments: 
Table 1

Results of DSC curing.

\begin{tabular}{llll}
\hline Systems & $\begin{array}{l}\text { Curing exotherm } \\
\Delta{\mathrm{H}\left(\mathrm{J} \mathrm{g}^{-1}\right)}\end{array}$ & $\begin{array}{l}\text { Onset } \\
\text { temperature } \\
\mathrm{T}_{\text {onset }}\left({ }^{\circ} \mathrm{C}\right)\end{array}$ & $\begin{array}{l}\text { Temperature of } \\
\text { maximal exothermicity } \\
\mathrm{T}_{\max }\left({ }^{\circ} \mathrm{C}\right)\end{array}$ \\
\hline TGMDA-DDS & 758 & 202 & 238 \\
DGEBA-DDS & 300 & 187 & 230 \\
\hline
\end{tabular}

- No significant changes are observed for signals due to aromatic rings $\left(1595,1509\right.$ and $\left.1362 \mathrm{~cm}^{-1}\right)$.

- The main changes are observed in the $1600-1800 \mathrm{~cm}^{-1}$ wavenumber range with maxima at 1682,1730 and $1767 \mathrm{~cm}^{-1}$ respectively ascribed to amides, carbonyls and formates. Absorbance for formates was checked from model compounds (see Appendix 1). The origin of each product will be commented in detail later. The $1760 \mathrm{~cm}^{-1}$ band was then considered as exclusively due to formates and exploited using $\varepsilon=500 \mathrm{l} \mathrm{mol}^{-1} \mathrm{~cm}^{-1}$ whereas our interpretation of mechanisms (see 'Discussion') lead us to attribute $1725 \mathrm{~cm}^{-1}$ to carboxylic acids (with a $6801 \mathrm{~mol}^{-1}$ absorptivity).

- A slow decrease is observed in the hydroxyl region (3500$3300 \mathrm{~cm}^{-1}$ ) suggesting that water elimination is negligible here. This will receive a more thorough attention in the following.

- A decrease is observed for the absorbance at $1039 \mathrm{~cm}^{-1}(\mathrm{Ar}-\mathrm{O}-$ $\mathrm{CH}_{2-}$ [24]) and for $1109 \mathrm{~cm}^{-1}$ one (secondary alcohol [25]). According to Fig. 4, the decrease of $1039 \mathrm{~cm}^{-1}$ absorbance is faster than 1109 one suggesting that methylene group in $\alpha$ position of ether is more sensitive to radical oxidation than methine group in $\alpha$ position of alcohol.
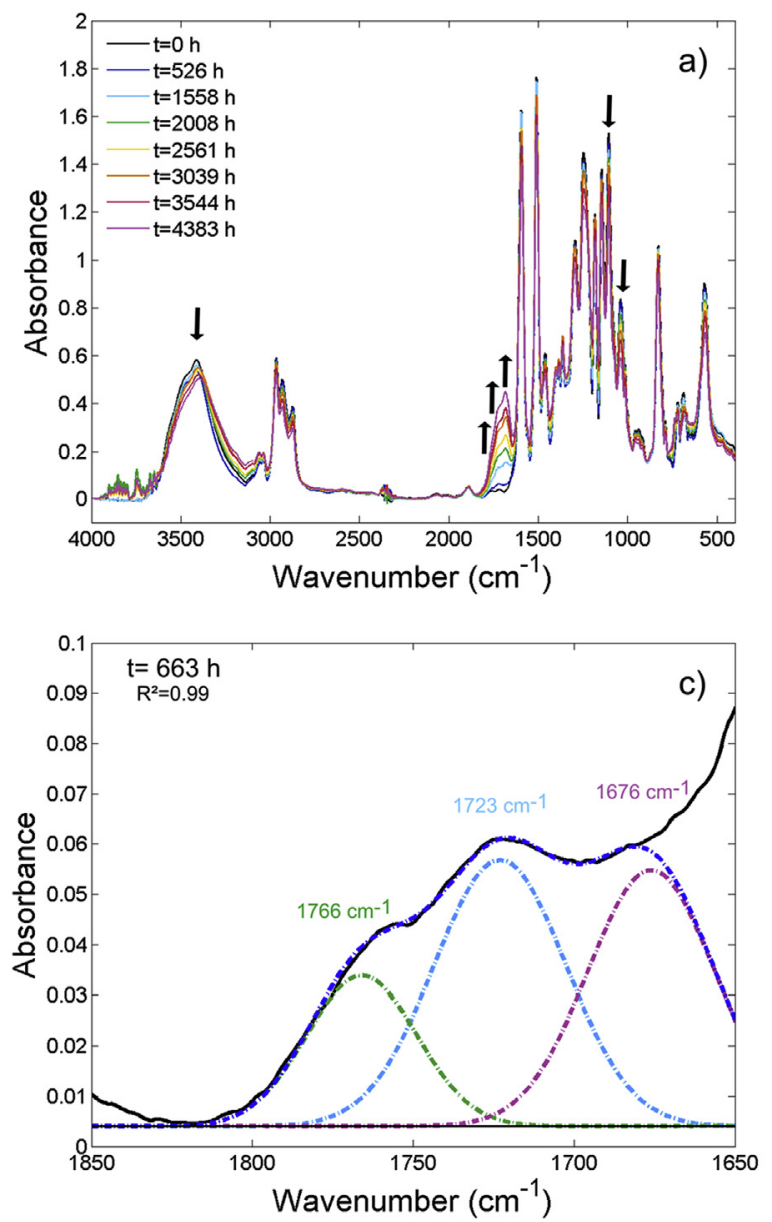

- According to Fig. 5, the decrease of 2871 and $2930 \mathrm{~cm}^{-1}$ absorbances (ascribed to methylenes [17]) seems faster than $2966 \mathrm{~cm}^{-1}$ one (ascribed to $\mathrm{CH}_{3}$ of DGEBA) as shown in Fig. 5 . According to the case of polycarbonate photo-oxidation [26,27] or DGEBA-diamine [28], isopropylidene groups could yield acetophenones $\left(1684 \mathrm{~cm}^{-1}\right)$. The absence of well-defined maxima at this wavenumber (Fig. 3) together with the slow decrease of the absorbance at $2966 \mathrm{~cm}^{-1}\left(\mathrm{C}_{-} \mathrm{CH}_{3}\right)$ demonstrates the higher stability of isopropylidene groups compared to the $\mathrm{C}-\mathrm{H}$ at vicinity of heteroatoms.

The region corresponding to amides and carbonyls (1600$1800 \mathrm{~cm}^{-1}$ ) is complex to analyze because of overlapping of several absorbances. The broad band was deconvoluted to better highlight the main oxidation stable products [29] (see Fig. 3c and 3d). It is observed that:

- formates $\left(1765 \mathrm{~cm}^{-1}\right)$ are formed as soon as the beginning of exposure.

- carbonyls predominate over amides at short exposure times (about $500 \mathrm{~h}$ ) whereas those later would predominate at relatively long exposure times ( $>4000 \mathrm{~h}$ ).

For ageing at $200^{\circ} \mathrm{C}$, formates and other carbonyls are also formed but the formation of amides is here observed to predominate even at short exposure times (Fig. 6).

\subsubsection{TGMDA-DDS}

Fig. 7 displays spectra for TGMDA-DDS after several ageing
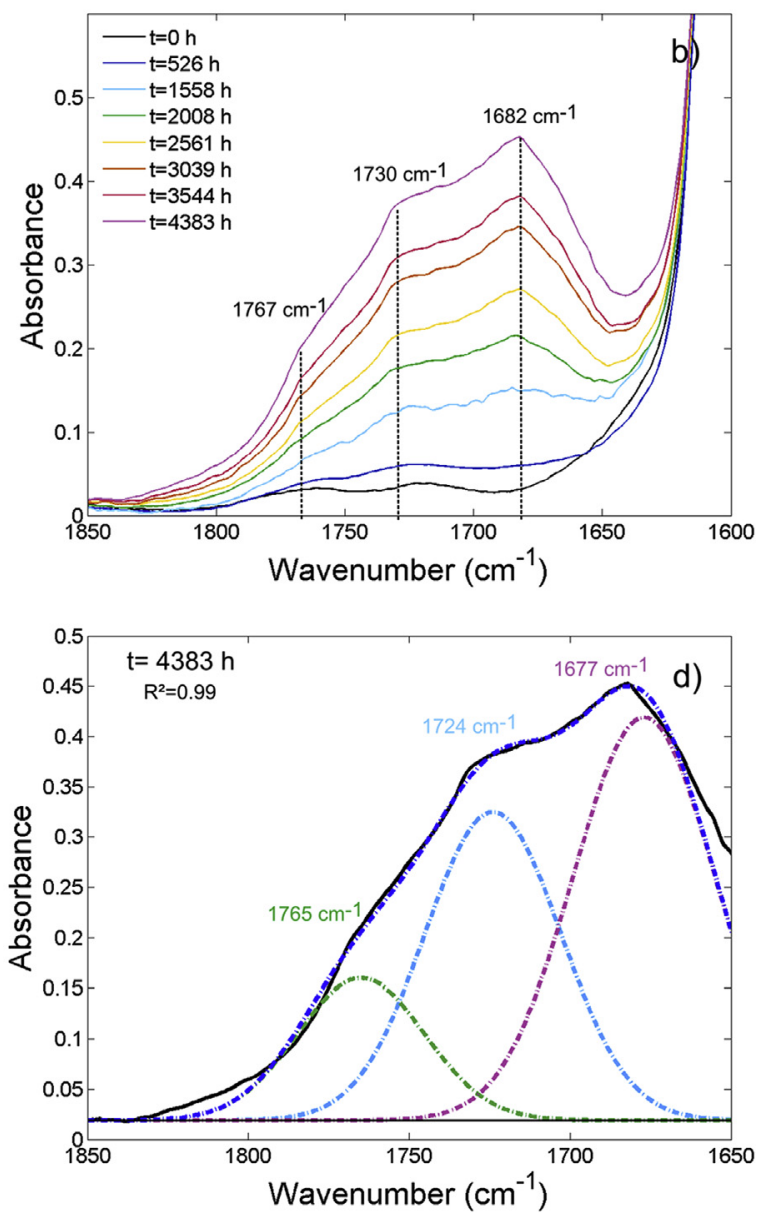

Fig. 3. FTIR spectra for DGEBA-DDS thermally oxidized at $120^{\circ} \mathrm{C}$ : full scale spectra (a), carbonyl region (b), deconvolution after $663 \mathrm{~h}(\mathrm{c})$ and $4383 \mathrm{~h}(\mathrm{~d})$ of thermal ageing. 


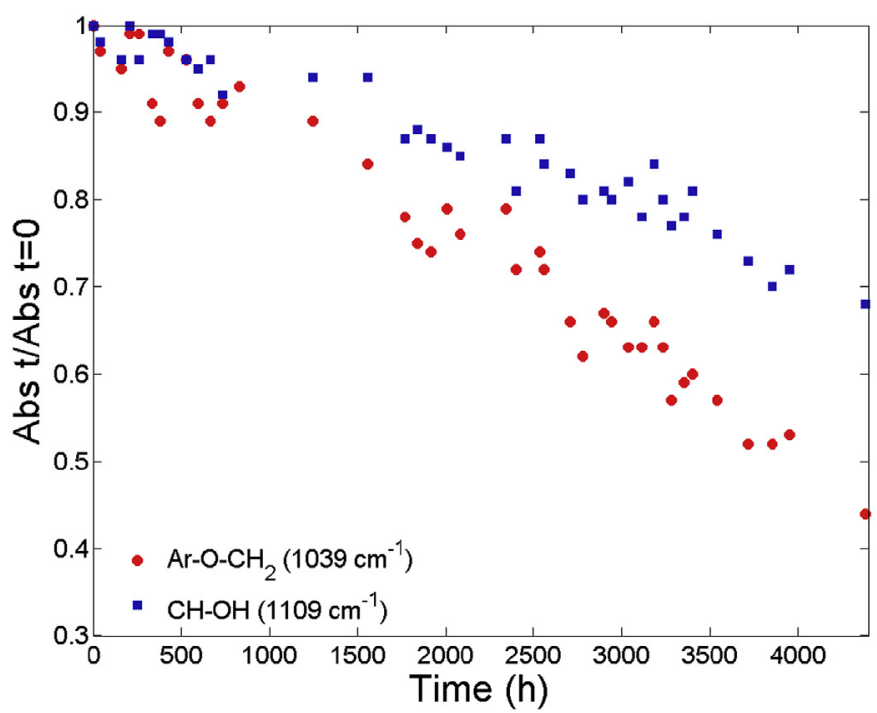

Fig. 4. Relative decrease of $-\mathrm{Ar}-\mathrm{O}-\mathrm{CH}_{2}-$ and $>\mathrm{CH}-\mathrm{OH}$ absorbance for DGEBA-DDS thermally oxidized at $120^{\circ} \mathrm{C}$.

durations at $120^{\circ} \mathrm{C}$. It calls for the following comments:

- The main change is the rapid formation of amides absorbing at $1675 \mathrm{~cm}^{-1}$ together with a secondary peak at $1723 \mathrm{~cm}^{-1}$ corresponding to several possible carbonyl groups (carboxylic acids, ketones ...) as discussed later. The amide absorbance is shifted at higher exposure times suggesting changes in its chemical surrounding. This peak is actually complex but a mechanistic discussion lead us to consider it is in great part due to carboxylic acids which were quantified using $\varepsilon=6801 \mathrm{~mol}^{-1} \mathrm{~cm}^{-1}$.

- Deconvolutions (Fig. 7c and d) suggest the presence of absorbances at 1645 and $1740 \mathrm{~cm}^{-1}$ that remain however negligible compared to 1675 and $1723 \mathrm{~cm}^{-1}$ ones at long exposure times (4500 h).

- The absorbances for methylenes visible at 2910 and $1460 \mathrm{~cm}^{-1}$ [16] are observed to decrease. It is however difficult at this stage to conclude which kind of methylene $\left(>\mathrm{CH}_{2}\right.$ between aromatic rings of TGMDA or in $\alpha$ position of nitrogens) is the most degraded.

As developed in the following, the amide build-up at $1675 \mathrm{~cm}^{-1}$ is obviously higher for TGMDA-DDS than for DGEBA-DDS. It means that methylene in $\alpha$ position of the nitrogen atom belonging to TGMDA monomer are more sensitive than methylene group in $\alpha$ position of DDS hardener at least at moderate temperature (such as $120^{\circ} \mathrm{C}$ ).

According to literature [14-16], the degradation mechanisms of TGMDA-DDS and DGEBA-DDS would involve a preliminary water elimination reaction followed by the oxidation of the allylic methylene groups in the generated $>\mathrm{N}-\mathrm{CH}_{2}-\mathrm{CH}=\mathrm{CH}-\mathrm{N}<$ groups. The occurrence of this reaction was tentatively assessed from the changes of the $>\mathrm{CH}-\mathrm{OH}$ and $=\mathrm{C}-\mathrm{H}$ stretching (Fig. 8). The absence of significant changes even at $200^{\circ} \mathrm{C}$ and $120^{\circ} \mathrm{C}$ in the timescale where amides are produced leads us to neglect, in a first approach, this reaction in the following of the paper.

\subsubsection{TGMDA monomers}

To better understand the origin of amides buildup, TGMDA monomer was aged at $120^{\circ} \mathrm{C}$ (Fig. 9). It is shown that:

- Oxidation products are very similar to those observed in TGMDA-DDS confirming the predominating role of methylene at the vicinity of nitrogen hold by TGMDA.
- The amides formation is very fast which confirms the instability of this last methylene group. As quantified more precisely later, its predominance over carbonyls one also indicates that methylene in $\alpha$ position of nitrogens are less stable than the oxirane rings or the $\mathrm{CH}_{2}$ in $\alpha$ position of ethers (apart if the carbonyls formed from those later are volatile products).

- The product formed at $1645 \mathrm{~cm}^{-1}$ could correspond to methyl quinone [27] formed from the oxidation of methylene group located between aromatic rings. However, its low quantity suggests that this group is quite stable in TGMDA and TGMDADDS (Figs. 7 and 10) and possibly more than the hydroxypropylether moiety.

\subsubsection{PKHJ and DGEBA monomers}

In order to understand the origin of formates $\left(1765 \mathrm{~cm}^{-1}\right)$ and carboxylic acids or ketones (about $1730 \mathrm{~cm}^{-1}$ ) when the substrate does not hold nitrogen atom, a linear phenoxy polymer (PKHJ) and DGEBA monomer were thermally aged so as to compare the reactivity of isopropylidene, $\mathrm{CH}_{2}$ in $\alpha$ position of ether and $\mathrm{CH}$ in $\alpha$ position of alcohol. Results are presented in Figs. 10-12.

Identically to DGEBA-DDS, a formate (absorbing at $1760 \mathrm{~cm}^{-1}$ ) is generated, together with other kinds of carbonyls absorbing at $1727 \mathrm{~cm}^{-1}$ (Fig. 10). Firstly, a part of this absorbance is due to the formates (see FTIR spectra in Appendix 1). The other part might come from the degradation of:

- methyl groups, but this seems negligible here since the peaks at $2966 \mathrm{~cm}^{-1}$ remain stable (Fig. 11) and there is no evidence for acetophenone coming from the isopropylidene degradation (absorbing at about $1684 \mathrm{~cm}^{-1}$ ).

- methines in $\alpha$ position of alcohol $(>\mathrm{CH}-\mathrm{OH})$ which seems also a minor route since the $1109 \mathrm{~cm}^{-1}$ band remains unchanged.

- formates themselves as it will be proposed in the 'Discussion' section (Scheme 1).

However, it seems reasonable to consider, in a first approach, that formates are the predominating species formed in $\mathrm{PKHJ}$ oxidation.

The comparison with oxidation of DGEBA monomer (Fig. 12) shows.

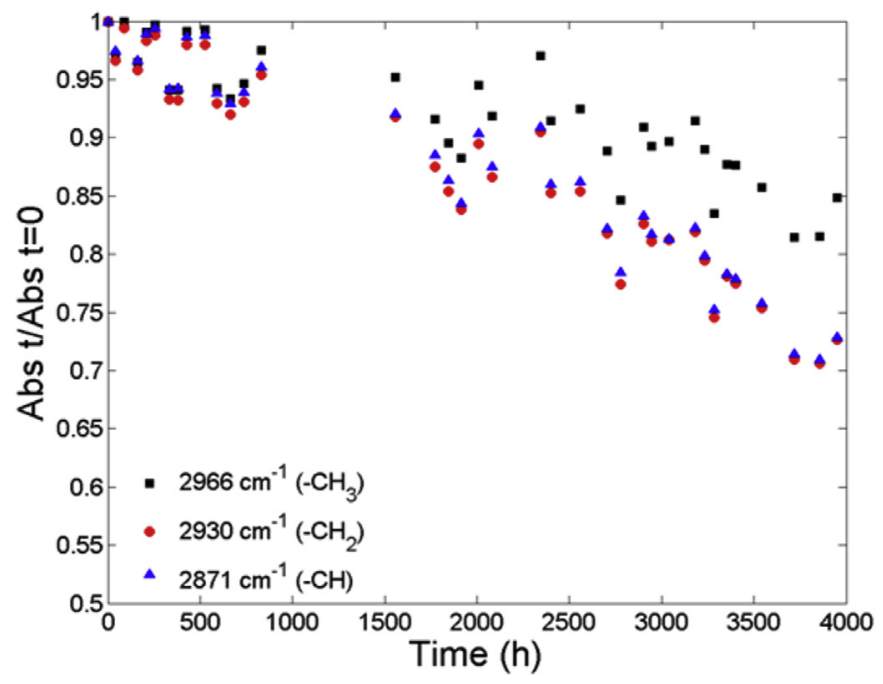

Fig. 5. Relative decrease of $-\mathrm{CH}_{3},-\mathrm{CH}_{2}$ - and $>\mathrm{CH}-$ absorbance for DGEBA-DDS thermally oxidized at $120^{\circ} \mathrm{C}$ 

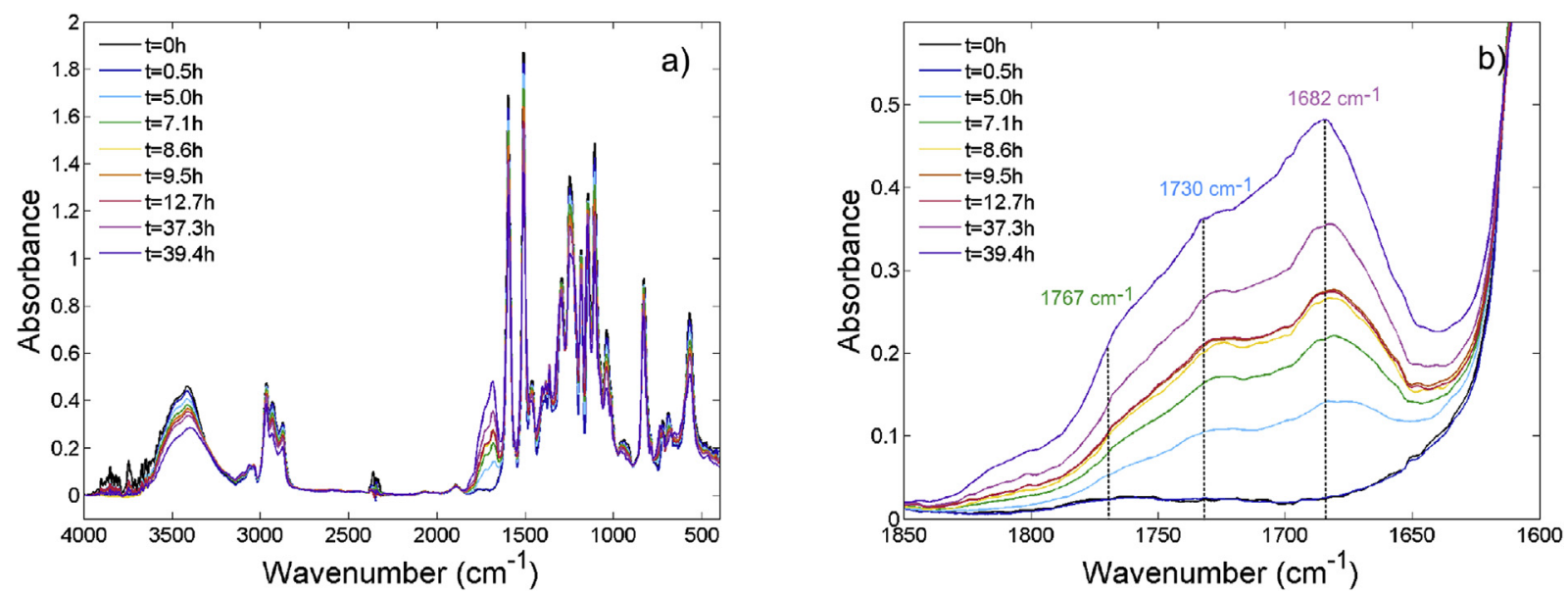

Fig. 6. FTIR spectra for DGEBA-DDS thermally oxidized at $200^{\circ} \mathrm{C}$ : full scale spectra (a) and carbonyl region (b).

- the appearance of an absorbance at $1760 \mathrm{~cm}^{-1}$, confirming its link with the $-\mathrm{Ar}-\mathrm{O}-\mathrm{CH}_{2}$ - group, the prominent role of which being confirmed since the formate predominates both in PHKJ and DGEBA in the earliest times of oxidation. Identically to DGEBA-DDS, formates will be considered as the key oxidation products and quantified using $\varepsilon=5001 \mathrm{~mol}^{-1} \mathrm{~cm}^{-1}$.

- a strong absorbance at $1727 \mathrm{~cm}^{-1}$ suggesting that oxirane rings are much more reactive than secondary alcohols.
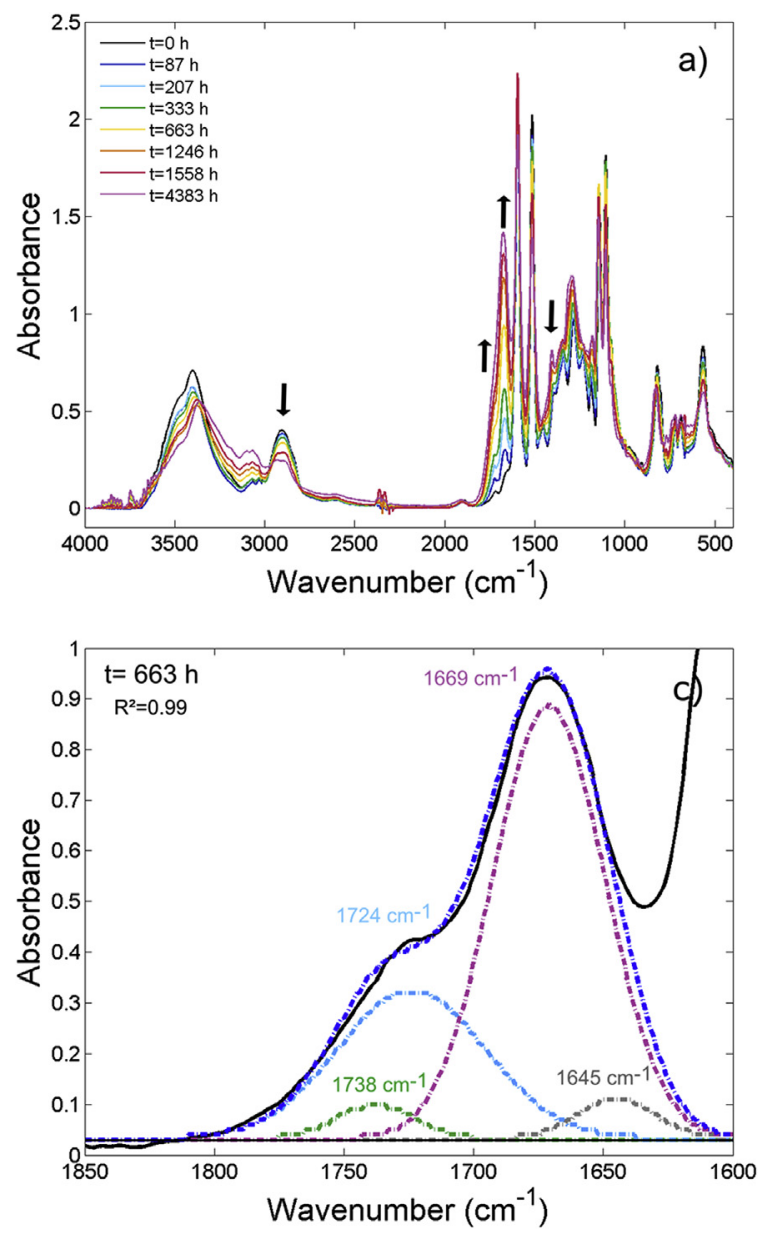

\subsection{Kinetics of buildup of stable products}

Concentrations in amides and carbonyls in TGMDA-DDS, DGEBA-DDS, PKHJ and TGMDA were estimated from Eq. (1). Carbonyl absorbance based on $1730 \mathrm{~cm}^{-1}$ absorbance actually is quite intricate:

- formates formed at $1765 \mathrm{~cm}^{-1}$ contribute to this peak (see Appendix).
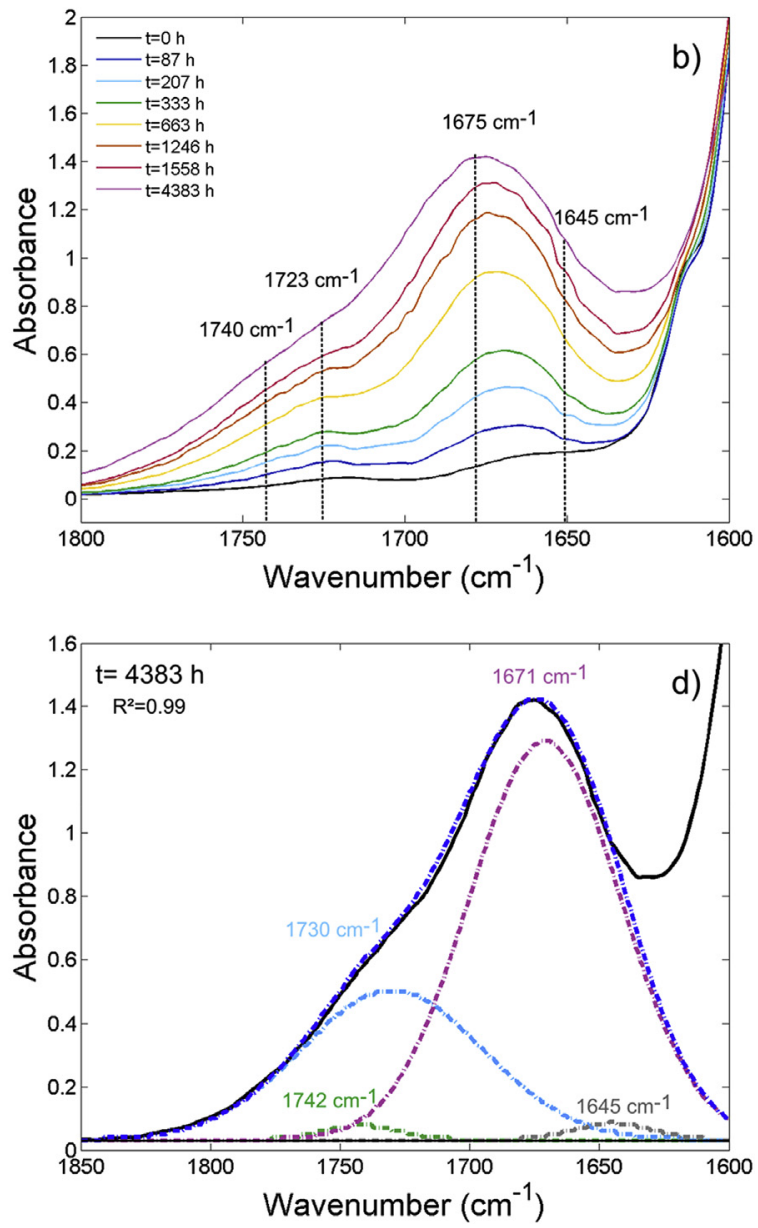

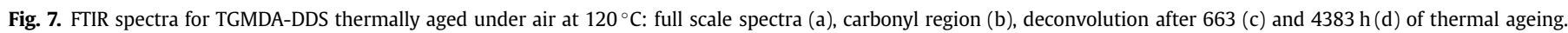



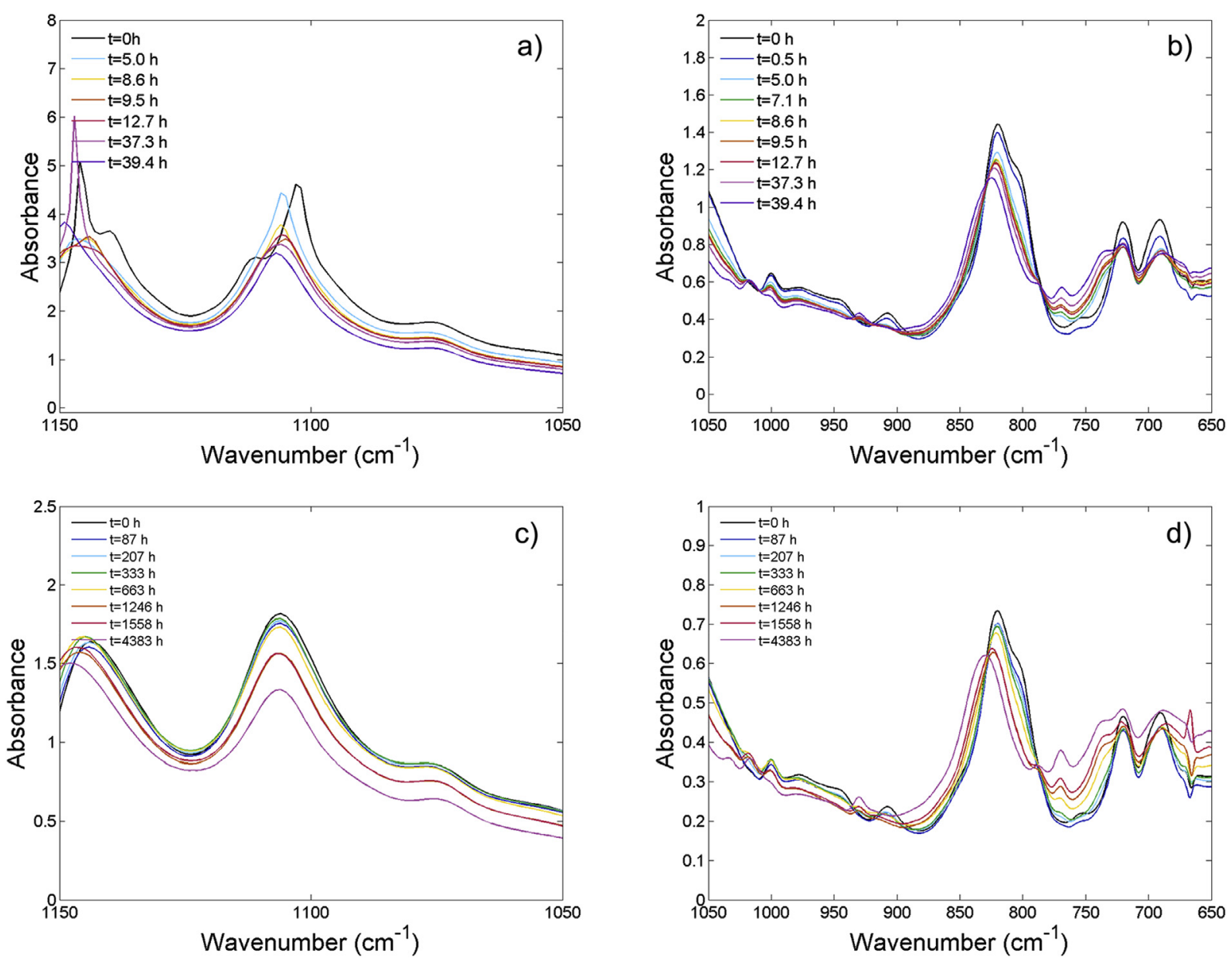

Fig. 8. FTIR spectra for TGMDA-DDS thermally aged under air at 200 (a, b) and $120^{\circ} \mathrm{C}(\mathrm{c}, \mathrm{d})$ in the $\mathrm{C}-\mathrm{O}(\mathrm{a}, \mathrm{c})$ and $=\mathrm{C}-\mathrm{H}$ stretching region $(\mathrm{b}, \mathrm{d})$.

- imides display a secondary absorbance at $1730 \mathrm{~cm}^{-1}$ (see also Appendix) with a $1 / 3$ ratio compared to $1675 \mathrm{~cm}^{-1}$ so the absorbance of carbonyls in TGMDA and TGMDA-DDS could be corrected using the following equation:

$A b s_{\text {corrected }}=A b s_{1730}-\frac{1}{3} A b s_{1675}$

As detailed later, it seems that carboxylic acids are the most probable species. In fact, this uncertainty does not change the main conclusions of the present paper.

Resulting concentrations changes for ageing at $120^{\circ} \mathrm{C}$ are plotted in Fig. 13 which calls for the following comments:

- Amide formation is always faster than carbonyls one.

- Thermal oxidation in TGMDA-DDS is always faster than in DGEBA-DDS in terms of amide formation which confirms that $\mathrm{CH}_{2}$ in $\alpha$ position of TGMDA significantly participate to the oxidation process (and even predominantly compared to $\mathrm{CH}_{2}$ in $\alpha$ position of DDS nitrogen atoms).

- Whatever the exposure temperature, no induction period is observed identically to similar systems [9-11,30]. The maximal rates for amides and carbonyls formation on DGEBA-DDS and TGMDA-DDS are gathered in Table 2.

- The formation of formates is faster in PKHJ than in DGEBA-DDS, consistently with the higher concentration in $-\mathrm{Ar}-\mathrm{O}-\mathrm{CH}_{2}-$ in PKHJ $\left(7 \mathrm{~mol} \mathrm{~kg}^{-1}\right)$ than in DGEBA-DDS $\left(4 \mathrm{~mol} \mathrm{~kg}^{-1}\right)$.
- In DGEBA DDS, it seems that $\mathrm{r}_{\mathrm{C}}$ (for $1730 \mathrm{~cm}^{-1}$ absorbance) is slightly higher than $r_{F}$ (for $1760 \mathrm{~cm}^{-1}$ absorbance) but lower than $r_{A}$ (for $1680 \mathrm{~cm}^{-1}$ absorbance). This will be used later for discussing on the relative reactivity of each site.

\section{Discussion}

The main aim of this section is to propose the most possible mechanisms (i.e. identify the main reactive groups) responsible for the formation of stable oxidation groups which will be used later to establish a scheme to be used for kinetic modeling.

\subsection{Possible mechanism of formation of stable products}

In DGEBA-DDS, two kinds of carbonyls are generated: formates absorbing at $1765 \mathrm{~cm}^{-1}$ and other carbonyl products absorbing at $1720-1730 \mathrm{~cm}^{-1}$. There are for us two possible pathways for explaining their formation:

- one based on the oxidation of methylene in $\alpha$ position of ether leading to a formate and another radical becoming a carboxylic acid (Scheme 1).

- one based on the oxidation of methine $\mathrm{C}-\mathrm{H}$ in $\alpha$ position of alcohol which will generate primary $-\mathrm{CH}_{2}{ }^{\circ}$ radical that will give a formate (Scheme 2).

According to Denisov [31], the alkoxy and peroxy in $\alpha$ position of hydroxyl could also decompose and give an aliphatic ketone (Scheme 3). However, such ketones would absorb at $1709 \mathrm{~cm}^{-1}$, that militates against that kind of mechanisms and maybe more 

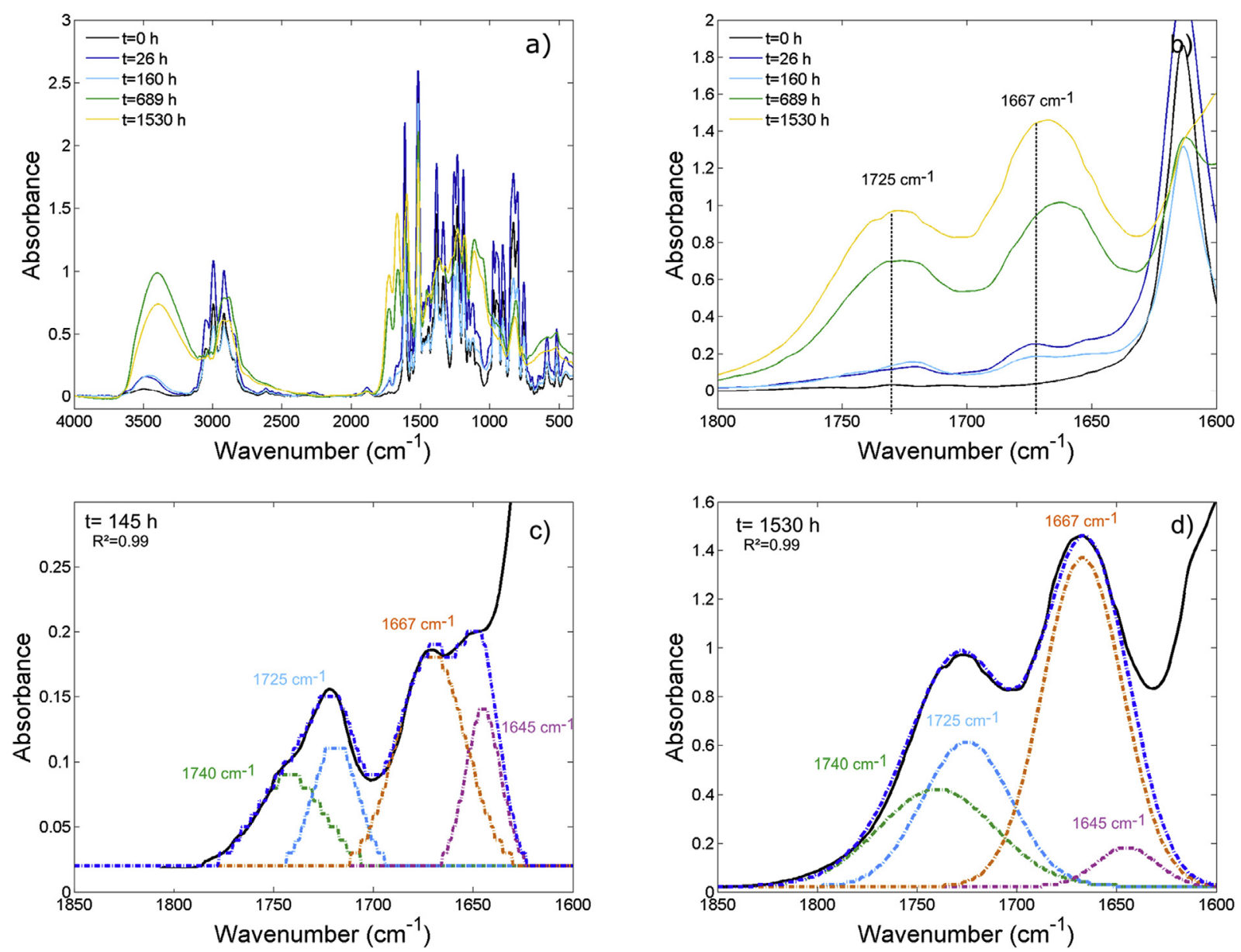

Fig. 9. FTIR spectra of TGMDA monomer thermally aged at $120^{\circ} \mathrm{C}$ under air: full scale spectra (a), carbonyl region (b), deconvolution after $145 \mathrm{~h}(\mathrm{c})$ and $1530 \mathrm{~h}$ (d) of thermal ageing.

generally against the reactivity of the secondary alcohol.

It is however clear that carbonyls actually are carboxylic acids (whatever they are formed from Scheme 1 or Scheme 2) which justifies the choice made for molar absorptivity (see '1.2. TGMDADDS' in the 'Result' section).

Amides originate from the oxidation of methylene in $\alpha$ position of nitrogen (Scheme 4a). They give either an amide or an $\alpha$ hydroxyamide expected to be unstable [32] and leading to a chain scission. The oxidation of $>\mathrm{CH}-\mathrm{OH}$ could also be considered as illustrated in Scheme 4b.

The formation of the various oxidation products of TGMDA-DDS can also be explained by several pathways: either the radical attack of $\mathrm{CH}_{2}$ in $\alpha$ position of nitrogens or $>\mathrm{CH}-\mathrm{OH}$. At high conversion degrees, it seems also that the amide can easily become an imide, identically to the case of polyamides [33] (Scheme 5) which would explain the shift observed for the $1675 \mathrm{~cm}^{-1}$ absorbance. A supplementary level of complexity for modeling the buildup of products absorbing near $1675 \mathrm{~cm}^{-1}$ is then expected.

The oxidation of the methylene located between the aromatic rings of TGMDA could also be responsible of the formation of a benzophenone absorbing at $1645 \mathrm{~cm}^{-1}$ (Scheme 6). According to Fig. 9, it seems however that this reaction is negligible.

Finally, this short mechanistic discussion does not permit to definitively conclude on the origin of each stable products, since each one can originate from several distinct mechanisms involving either $>\mathrm{N}-\mathrm{CH}_{2}-$ or $>\mathrm{CH}-\mathrm{OH}$ for amides, and $-\mathrm{O}-\mathrm{CH}_{2}-$ or $>\mathrm{CH}-\mathrm{OH}$ for carbonyls. We will hence discuss on the reactivity of each reactive site basing on the available thermochemical and kinetic data existing for comparable model systems.

\subsection{On the relative reactivity of each site}

Let us recall that the kinetics parameters for the propagation reaction $\mathrm{POO}^{\circ}+\mathrm{PH} \rightarrow \mathrm{POOH}+\mathrm{P}^{\circ}$ depend on the Bond Dissociation Energy of the broken $\mathrm{C}-\mathrm{H}\left(\mathrm{BDE}_{\mathrm{C}-\mathrm{H}}\right)$ [34]:

$\log k_{3}^{S P O O^{\circ}}\left(30^{\circ} \mathrm{C}\right)=16,4-0.0478 \times B D E_{C-H}$

$E_{3}=0.55 \times\left(B D E_{(C-H)}-261,5\right)$

Here, PH represents $\mathrm{C}-\mathrm{H}$ in $\alpha$-position of oxygen, hydroxyl or nitrogen groups. Data for relevant model systems are gathered in Table 3.

The Bond Dissociation Energy of $\mathrm{C}-\mathrm{H}$ in $\alpha$ of hydroxy in $>\mathrm{CH}-\mathrm{OH}$ strongly changes with the nature of substituents. The value for isopropanol (which is the model compound the closest to secondary alcohol group in epoxy-diamine and $\mathrm{PKHJ}$ ) is clearly higher than values of $\mathrm{C}-\mathrm{H}$ in $>\mathrm{N}-\mathrm{CH}_{2}-$ and $\mathrm{Ar}-\mathrm{O}-\mathrm{CH}_{2}$ ( $\mathrm{NB}$ : the same reasons lead us to neglect in a first approach the reactivity of tertiary methyl groups in DGEBA-DDS (since BDE is clearly higher than $400 \mathrm{~kJ} \mathrm{~mol}^{-1}$ ).

This suggests that $>\mathrm{CH}-\mathrm{OH}$ are less likely to undergo a radical attack and militates in favor of mechanisms presented in Schemes 1 and $4 \mathrm{a}$ compared to Schemes 2, 3 and $4 \mathrm{~b}$. It is consistent with the faster decrease of $\mathrm{C}-\mathrm{H}$ in $\mathrm{Ar}-\mathrm{O}-\mathrm{CH}_{2}$ - compared to $>\mathrm{CH}-\mathrm{OH}$ (Fig. 4). It also brings a supplementary discussion of Fig. $10: 1730 \mathrm{~cm}^{-1}$ seems predominating but this peak features a contribution of the 1760 peak. Since species absorbing at $1730 \mathrm{~cm}^{-1}$ have a higher molar 

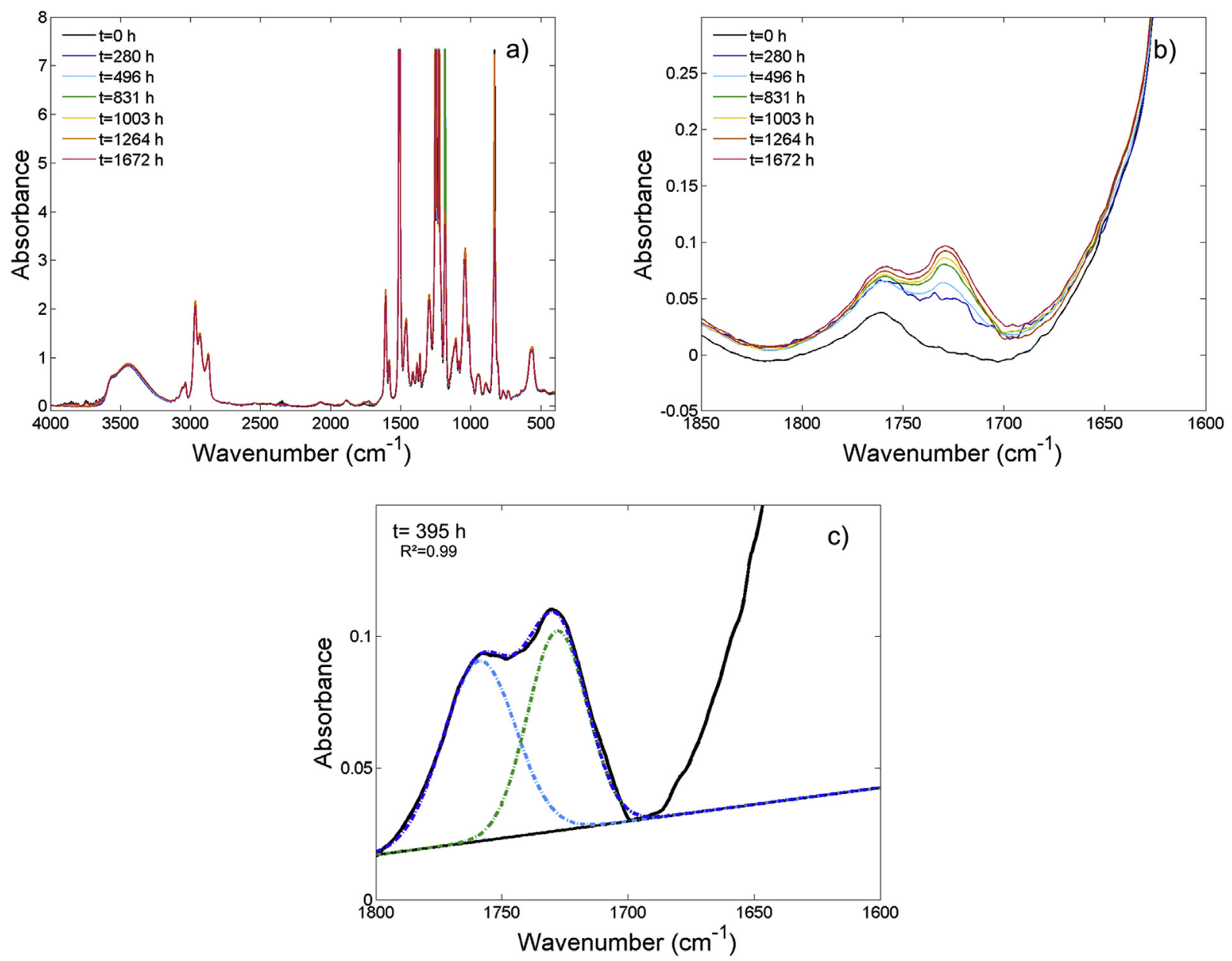

Fig. 10. FTIR spectra of PKHJ thermally aged at $120^{\circ} \mathrm{C}$ under air: full scale spectra (a), carbonyl region (b), deconvolution after $395 \mathrm{~h}$ (c) and $3591 \mathrm{~h}(\mathrm{~d})$ of thermal ageing.

absorptivity than $1730 \mathrm{~cm}^{-1}$, it confirms the here above conclusion. However, the full understanding of the relative rates of oxidation product formation (formates, carbonyls and amides in DGEBA-DDS for example - see Fig. 13) and the interplay with them remains an open takes requiring, for example, the use of a co-oxidation kinetic model [38].

The oxidizability of each site can also be expressed by the ratio $\mathrm{k}_{3}^{2} / \mathrm{k}_{6}$ ( $\mathrm{k}_{3}$ and $\mathrm{k}_{6}$ being respectively the rate constants for the $\mathrm{POO}^{\circ}+\mathrm{PH} \rightarrow \mathrm{POOH}+\mathrm{P}^{\circ}$, and $\mathrm{POO}^{\circ}+\mathrm{POO}^{\circ} \rightarrow$ inactive product). Some possible values are given in Table 4 [39-41] and confirm the lower oxidizability of $>\mathrm{CH}-\mathrm{OH}$ and of the methylene located between aromatic rings in TGMDA.

Let us note that the above estimations are done for methyl $\left(-\mathrm{CH}_{3}\right)$ in $\alpha$ position of amines. In DEGBA-DDS and TGMDA-DDS, the reactive sites are $\mathrm{CH}_{2}$ expected to be less stable which strengthens our reasoning. In other words, those kinetic and thermochemical data point out that $>\mathrm{N}-\mathrm{CH}_{2}$ - and $-\mathrm{O}-\mathrm{CH}_{2}$ - play a major role in the degradation course compared to $>\mathrm{CH}-\mathrm{OH}$ and more surprisingly in a certain extent $-\mathrm{Ar}-\mathrm{CH}_{2}-\mathrm{Ar}-$. It remains to better understand the role of the chemical surrounding on the reactivity of methylene in $\alpha$ position of nitrogens to better understand the relative contribution of $\mathrm{CH}_{2}$ in $\alpha$ position of the nitrogen hold by TGMDA or DDS.

\subsection{On the origin of amides and the role of DDS hardener}

According to Table 3, the ratio of rate of amides formation in TGMDA-DDS over rate of amides formation in DGEBA-DDS decreases from about 35 at $80^{\circ} \mathrm{C}$ to 3.5 at $200^{\circ} \mathrm{C}$. Let us recall that those rates are linked to the concentration in reactive sites by:

$r_{o x}=\left(\frac{k_{3}^{2}}{k_{6}}\right)[P H]^{2}$

where $\mathrm{k}_{3}$ and $\mathrm{k}_{6}$ are respectively the rate constants for propagation $\left(\mathrm{POO}^{\circ}+\mathrm{PH} \rightarrow \mathrm{POOH}+\mathrm{P}^{\circ}\right)$ and termination $\left(\mathrm{POO}^{\circ}+\mathrm{POO}^{\circ} \rightarrow\right.$ inactive products), and $[\mathrm{PH}]$ is the concentration in reactive sites that can be estimated from:

$[P H]=\frac{\text { Number of oxidizable sites }}{M_{U C R}}$

$M_{U C R}$ being the molar mass of the repetitive constitutive unit (i.e. $928 \mathrm{~g} \mathrm{~mol}^{-1}$ for DGEBA DDS and $670 \mathrm{~g} \mathrm{~mol}^{-1}$ for TGMDA-DDS). It leads to:

- $[\mathrm{PH}]_{\alpha-\mathrm{N}}=4.3 \mathrm{~mol} \mathrm{~kg}^{-1}$ in DGEBA-DDS

- $[\mathrm{PH}]_{\alpha-\mathrm{N}}=12 \mathrm{~mol} \mathrm{~kg}^{-1}$ in TGMDA-DDS (with $[\mathrm{PH}]_{\alpha-}$ $\mathrm{N}=6 \mathrm{~mol} \mathrm{~kg}^{-1}$ for $\mathrm{CH}_{2}$ in $\alpha$ position of the nitrogen atom hold by TGMDA and $[\mathrm{PH}]_{\alpha-\mathrm{N}}=6 \mathrm{~mol} \mathrm{~kg}{ }^{-1}$ for $\mathrm{CH}_{2}$ in $\alpha$ position of the nitrogen atom hold by DDS).

In other words, if all $\mathrm{CH}_{2 \alpha-\mathrm{N}}$ would have the same reactivity, the ratio $\left(r_{\text {amide }}\right)_{\text {TGMDA-DDS }} /\left(r_{\text {amide }}\right)_{\text {DGEBA-DDS }}$ should be close to (12/ $4.3)^{2}-10$ irrespectively of the temperature. However, this ratio is clearly higher than 10 at $120^{\circ} \mathrm{C}$ meaning that $\mathrm{CH}_{2}$ in $\alpha$ position of nitrogen hold by TGMDA are much more reactive than $\mathrm{CH}_{2}$ in $\alpha$ 

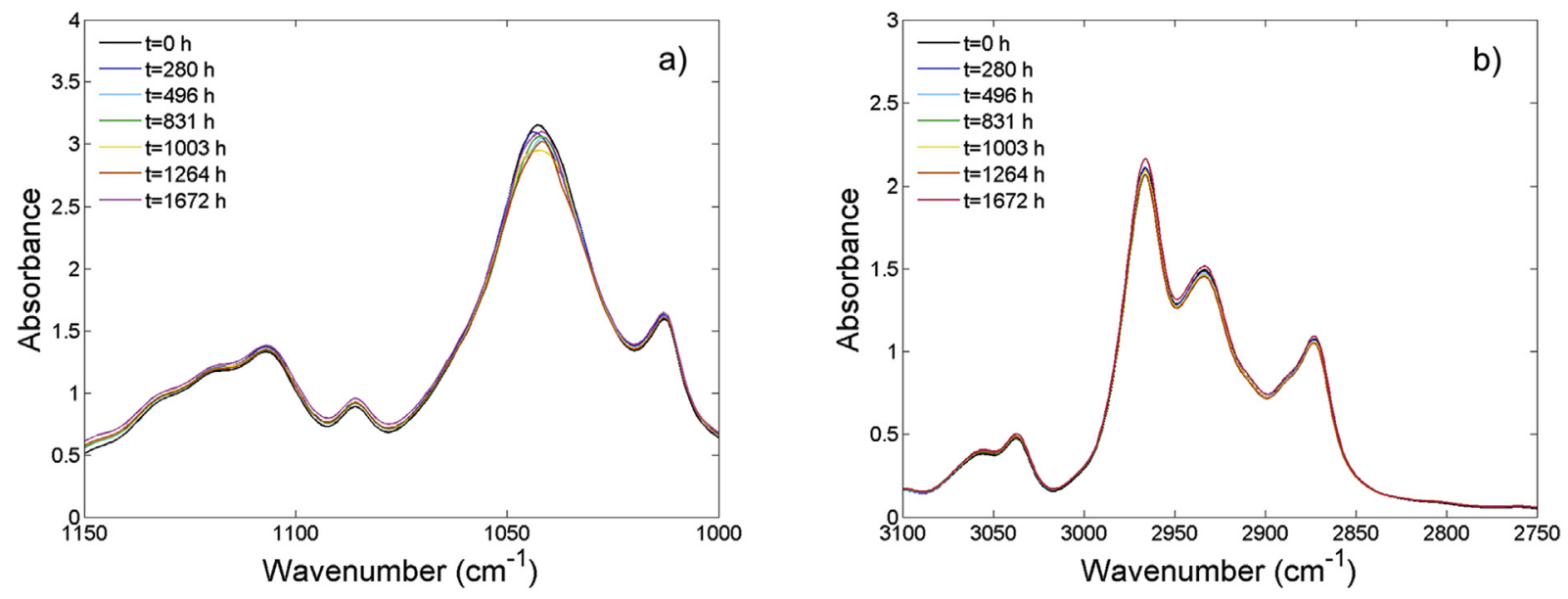

Fig. 11. FTIR spectra of PKHJ thermally aged at $120^{\circ} \mathrm{C}$ under air in the region of $\mathrm{C}-\mathrm{O}$ (a) and $\mathrm{C}-\mathrm{H}$ stretching (b).
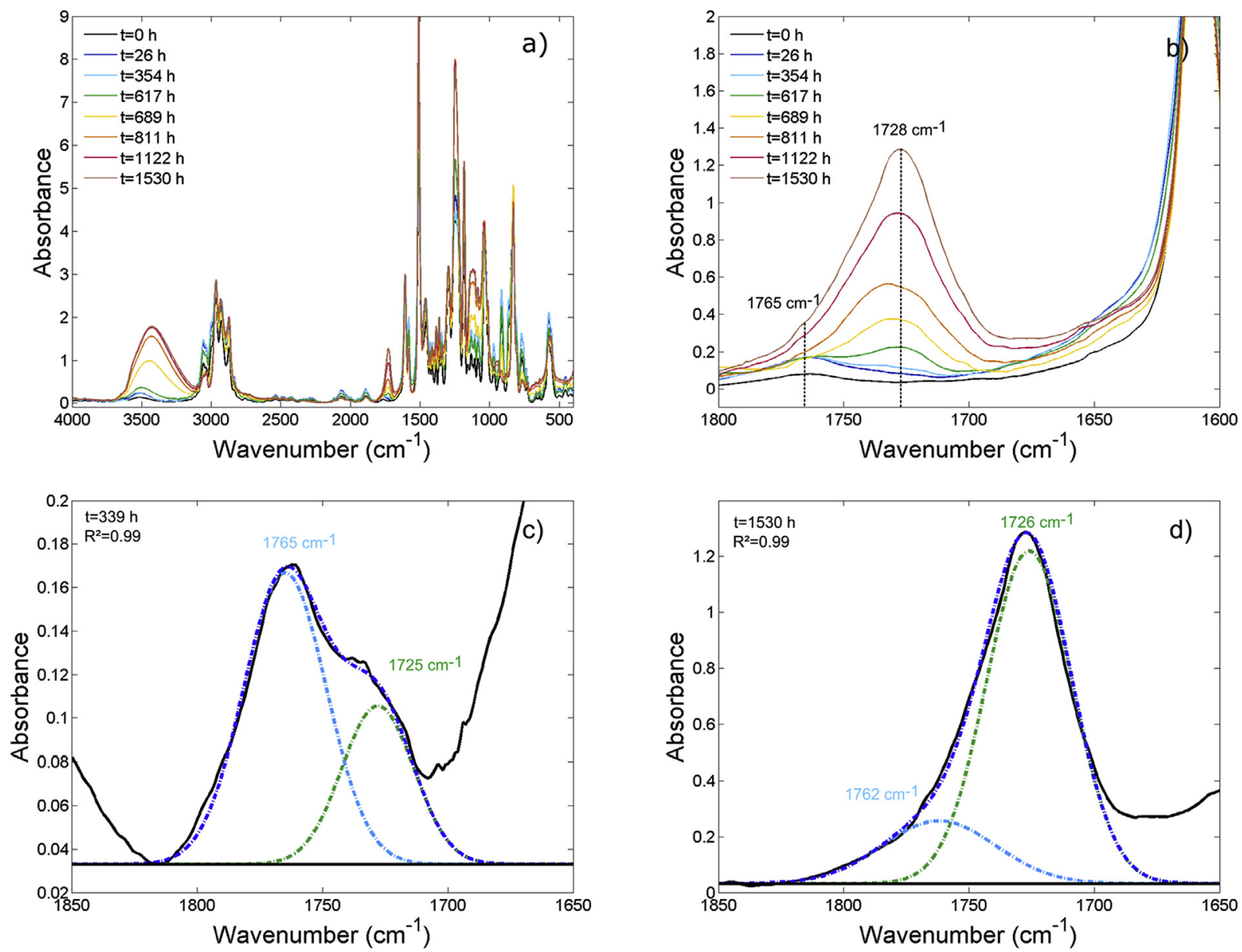

Fig. 12. FTIR spectra of DGEBA thermally aged at $120^{\circ} \mathrm{C}$ under air: full scale spectra (a), carbonyl region (b), deconvolution after $335 \mathrm{~h}$ (c) and $1530 \mathrm{~h}$ (d) of thermal ageing.

position of DDS (this difference decreasing with temperature). This seems confirmed by the comparison of amide formation in TGMDADDS and TGMDA at $120^{\circ} \mathrm{C}: r_{\text {amide }}=6.7 \times 10^{-7} \mathrm{moll}^{-1} \mathrm{~s}^{-1}$ with $[\mathrm{PH}]_{\alpha-\mathrm{N}}=9 \mathrm{~mol} \mathrm{l}^{-1}$ in TGMDA versus $\mathrm{r}_{\text {amide }}=5.6 \times 10^{-7} \mathrm{moll}^{-1} \mathrm{~s}^{-1}$ with $[\mathrm{PH}]_{\alpha-\mathrm{N}}=12 \mathrm{moll}^{-1}$ in TGMDA-DDS. It involves that $10^{7} \times \mathrm{r}_{\text {amide }} /[\mathrm{PH}]^{2}=0.084$ in TGMDA versus 0.039 in TGMDA-DDS pointing out the highest reactive of methylenes vicinal to $\mathrm{N}$ hold by TGMDA compared to $\mathrm{N}$ hold by DDS.

According to Eichler et al. [42], the presence of attractive $\mathrm{SO}_{2}$ group induces a decrease of the electronic density on DDS nitrogen atom (for example compared to DiaminoDiphenylMethane). This explains for example the difference in reactivity towards epoxies and the matter that the polymerization onset occurs at lower temperature for epoxies cured with DDM than with DDS [43].

In other words, the DDS effect induces:

- either a higher Bond Dissociation Energy (than reported in Table 3) and then a slower propagation kinetics. Interestingly, it can be noted a higher Bond Dissociation Energy means a higher activation energy for propagation (Eq. (4)) so that the reaction 


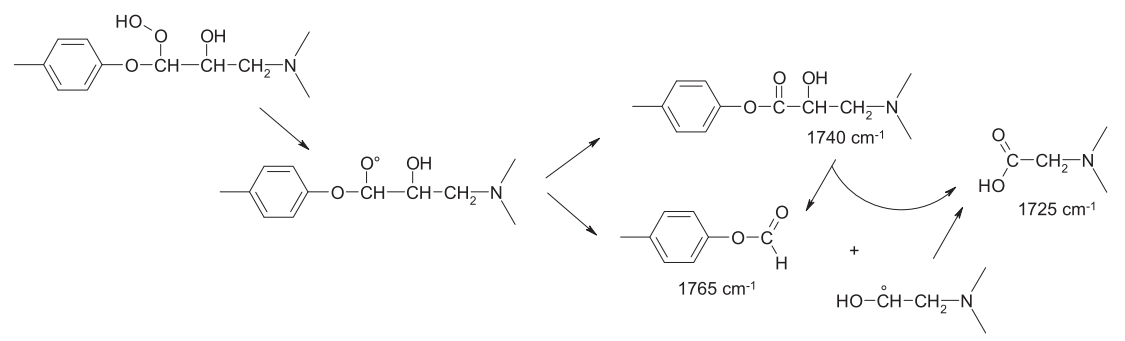

Scheme 1. Possible oxidation mechanism of $-\mathrm{Ar}-\mathrm{O}-\mathrm{CH}_{2}$ - group in DGEBA-DDS.
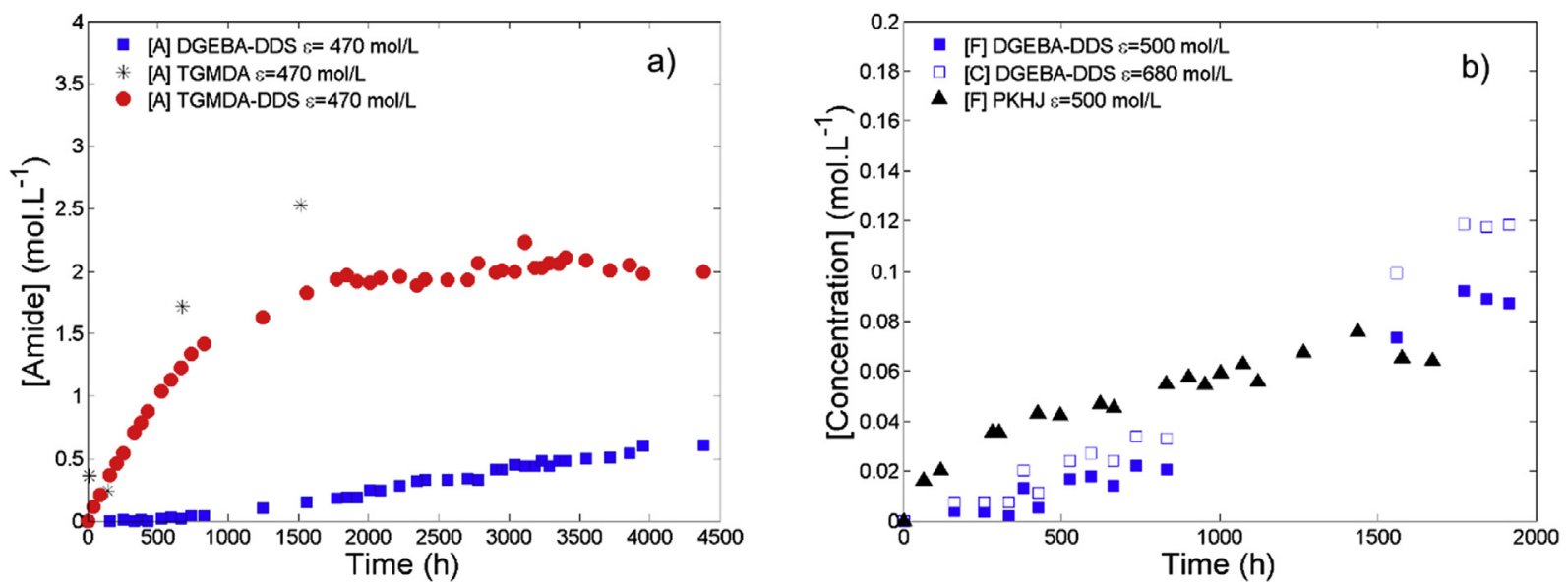

Fig. 13. Changes in amides $[\mathrm{A}]$ and carbonyls $[\mathrm{C}]$ for systems under study thermally aged under air at $120^{\circ} \mathrm{C}$.

Table 2

Maximal rates for amides and carbonyls formations at 80,120 and $200^{\circ} \mathrm{C}$ under air.

\begin{tabular}{|c|c|c|c|c|}
\hline Systems & DGEBA-DDS & & \multicolumn{2}{|l|}{ TGMDA-DDS } \\
\hline \multicolumn{5}{|c|}{ Maximal rate of amides formation $\left(\mathrm{mol} \mathrm{l}^{-1} \mathrm{~s}^{-1}\right)$} \\
\hline $\mathrm{r}_{\mathrm{ox}} 80^{\circ} \mathrm{C}$ & $4.69 \times 10^{-10}$ & & $1.87 \times 10^{-8}$ & \\
\hline $\mathrm{r}_{\mathrm{ox}} 120^{\circ} \mathrm{C}$ & $3.75 \times 10^{-8}$ & & $5.61 \times 10^{-7}$ & \\
\hline $\mathrm{r}_{\mathrm{ox}} 200^{\circ} \mathrm{C}$ & $1.20 \times 10^{-5}$ & & $4.15 \times 10^{-5}$ & \\
\hline \multicolumn{5}{|c|}{ Maximal rate for carbonyls formation $\left(\mathrm{mol} \mathrm{l}^{-1} \mathrm{~s}^{-1}\right)$} \\
\hline & & ${ }^{*}[\mathrm{C}]$ corr & & $*[C] \operatorname{corr}$ \\
\hline $\mathrm{r}_{\mathrm{ox}} 80^{\circ} \mathrm{C}$ & $3.36 \times 10^{-10}$ & $2.22 \times 10^{-10}$ & $5.56 \times 10^{-9}$ & $1.94 \times 10^{-9}$ \\
\hline $\mathrm{r}_{\mathrm{ox}} 120^{\circ} \mathrm{C}$ & $2.22 \times 10^{-8}$ & $1.38 \times 10^{-8}$ & $1.10 \times 10^{-7}$ & $3.28 \times 10^{-8}$ \\
\hline $\mathrm{r}_{\mathrm{ox}} 200^{\circ} \mathrm{C}$ & $9.42 \times 10^{-6}$ & $3.55 \times 10^{-6}$ & $1.16 \times 10^{-5}$ & $2.83 \times 10^{-6}$ \\
\hline
\end{tabular}

* The corrected concentration is obtained according to the Equation (2).

on $\mathrm{CH}_{2}$ in $\alpha$ position of DDS becomes possible at higher temperatures consistently with the decrease of the ratio $\left(r_{a m}\right.$ ide)TGMDA-DDS $/\left(r_{\text {amide }}\right)_{\text {DGEBA-DDS. }}$

- or a «stabilization » of the hydroperoxides but in principle, the stability of hydroperoxides does not influence the maximal rate of oxidation (according to Eq. (5))

Finding the right explanation, together with refining the data given in Tables 3 and 4, remains open and requires for us the need of quantum calculations $[44,45]$ to get more quantitative explanations and more precise estimation of Bond Dissociation Energies at the ageing temperature (instead of $298 \mathrm{~K}$ as usually given in monographs).

\section{Conclusions}

The embrittlement of thermally oxidized epoxy-diamine networks is linked to the disappearance of the hydroxypropylether function, which is the main reactive group in DGEBA-DDS and possibly in TGMDA-DDS. In this work, we tentatively identified the main reactive sites in those epoxy systems by studying their thermal degradation with the help of comparison with some model compounds displaying some structural similarities and quantitative arguments (assessment of rates of formation of stable products, estimated values of Bond Dissociation Energies). It was concluded that:

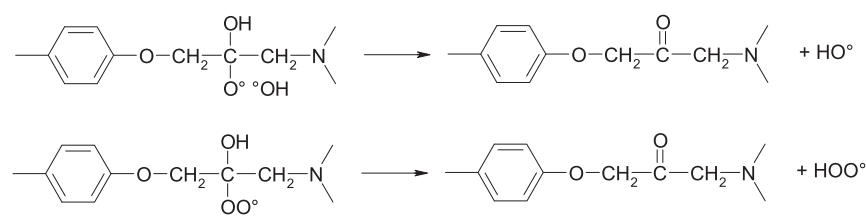

Scheme 3. Possible pathways for the formation of aliphatic ketones.

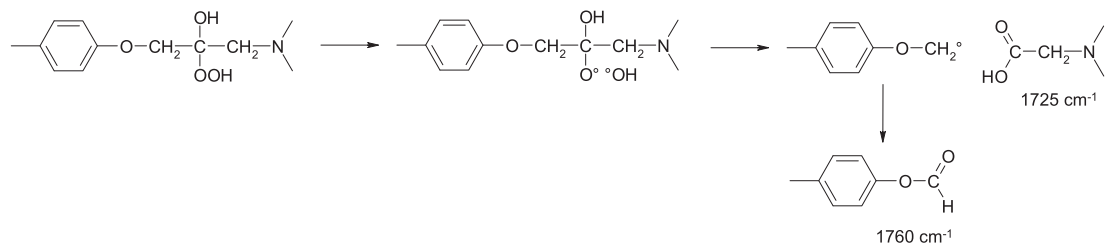

Scheme 2. Possible oxidation mechanism of $>\mathrm{CH}-\mathrm{OH}$ group in DGEBA-DDS. 


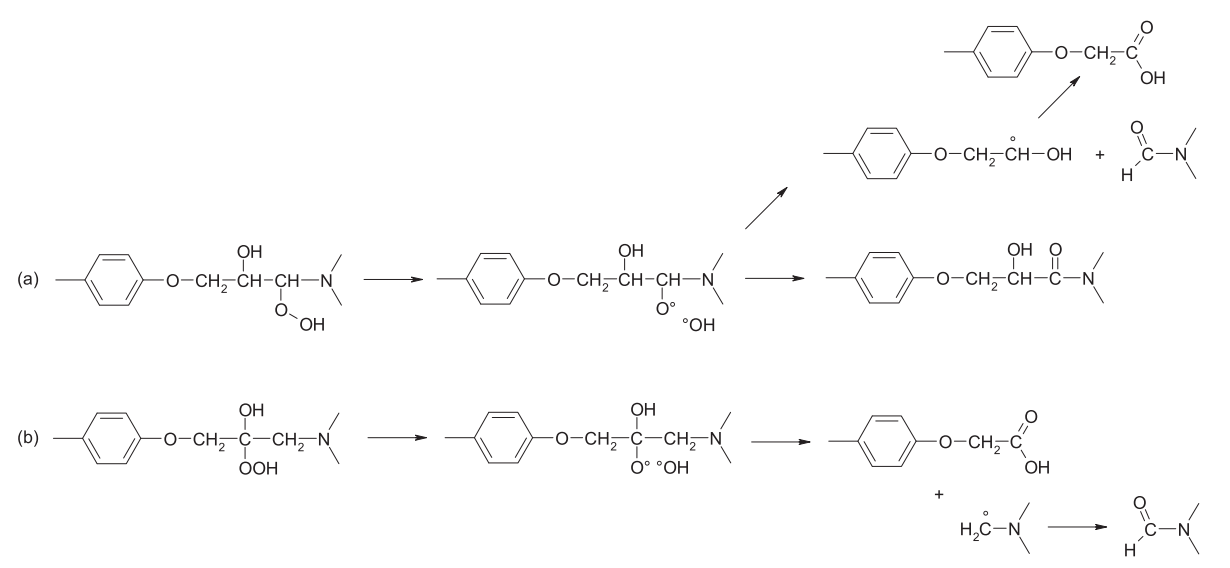

Scheme 4. Possible pathways of amide by-products from oxidation of methylenes in $\alpha$ position of nitrogen (a) or $\beta$ one (b).

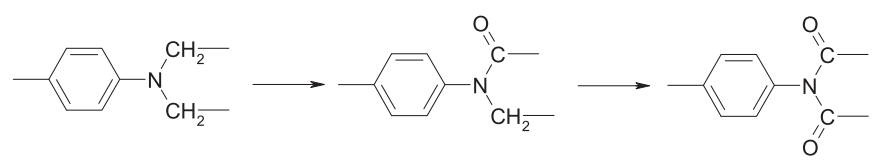

Scheme 5. Formation of imides in TGMDA and TGMDA-DDS.<smiles>CN(C)c1ccc(Cc2ccc(N(C)C)cc2)cc1</smiles>

Scheme 6. Possible mechanism for benzophenone formation in TGMDA-DDS.

- the $\mathrm{CH}_{2}$ in $\alpha$ position of ether is more reactive than $>\mathrm{CH}-\mathrm{OH}$ in DGEBA-DDS and leads to a formate. The $\mathrm{CH}_{2}$ in $\alpha$ position of DDS is expected to generate an amide, and can also be involved either at relatively long times (at low temperature) and more significantly at higher temperatures.
Table 4

Oxidizability of some model compounds.

\begin{tabular}{lll}
\hline & $\mathrm{k}_{3} /\left(2 \mathrm{k}_{6}\right)^{1 / 2}\left(120^{\circ} \mathrm{C}\right)$ & $\mathrm{k}_{3} /\left(2 \mathrm{k}_{6}\right)^{1 / 2}\left(200{ }^{\circ} \mathrm{C}\right)$ \\
\hline $\mathrm{PhNMe}_{2}$ & 0.152 & 0.360 \\
& 0.105 & 0.313 \\
$\mathrm{Ar}-\mathrm{CH}_{2}-\mathrm{Ar}$ & 0.008 & 0.061 \\
$\mathrm{Me}_{2} \mathrm{CHOH}$ & 0.006 & 0.086 \\
\hline
\end{tabular}

- the $\mathrm{CH}_{2}$ in $\alpha$ position of nitrogen hold by TGMDA seems to be the main reactive site in TGMDA-DDS and generates an amide. It seems to be much more reactive (at low temperature) than $\mathrm{CH}_{2}$ in $\alpha$ position of DDS.

In the past, the main attempts to model the kinetics of epoxies thermal oxidation assumed the unicity of reactive sites i.e. that the reactivity of all $\mathrm{C}-\mathrm{H}$ present in the hydroxypropylether is ruled by a

Table 3

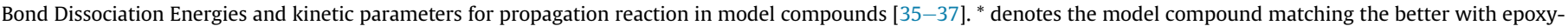
diamine systems under investigation. (NB: a supplementary discussion of those values is given in Appendix 2).

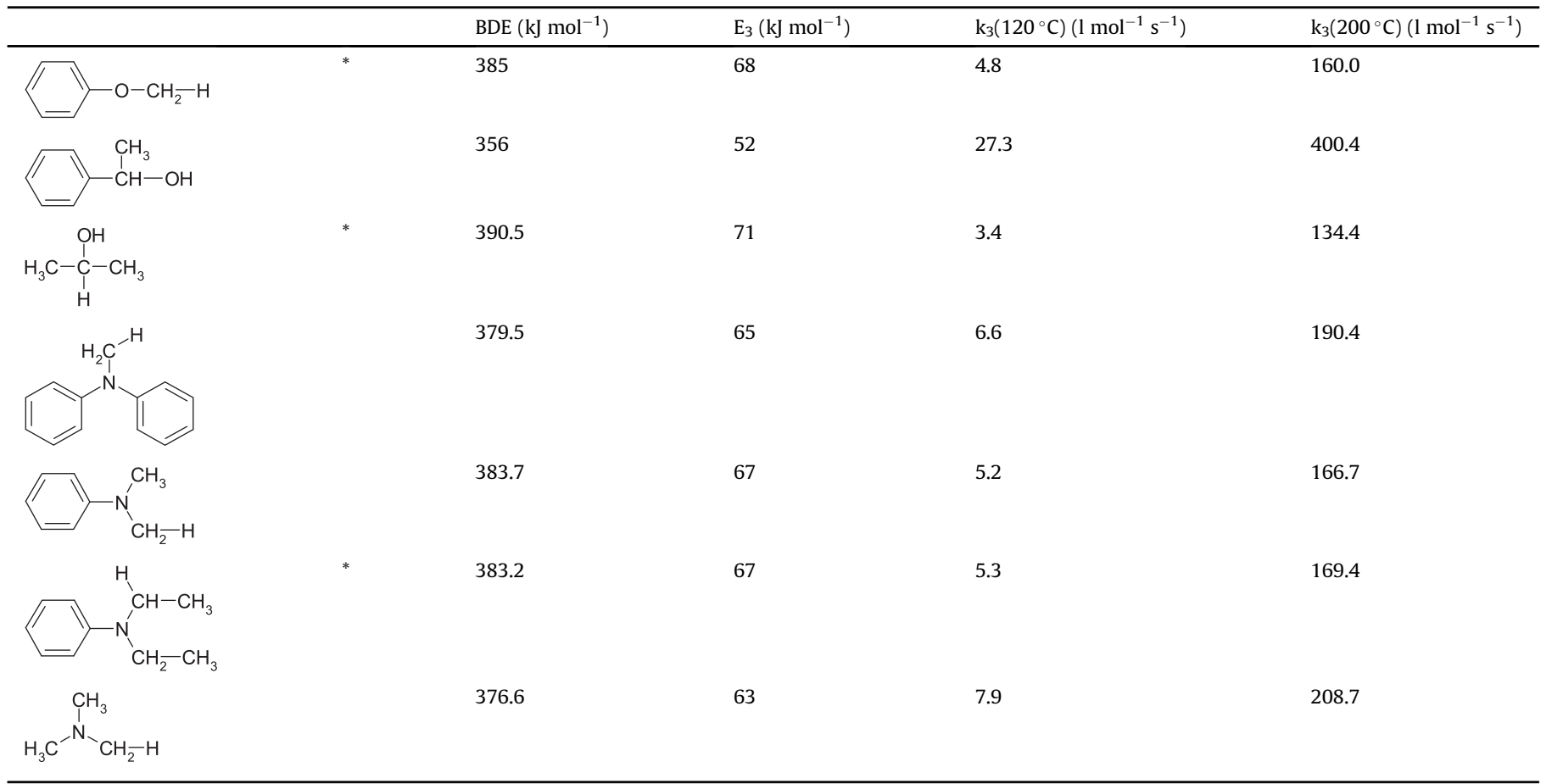


unique set of rate constants. It seems now clear that only a cooxidation kinetic model (mixing various kinds of reactive units) can describe the degradation of epoxy-diamine networks [36]. The adjustment of the numerous rate constants requires a deeper investigation which goes out of the scope of the present paper. However, the study of model compounds (as presented in this work) will be helpful to estimate most of them as illustrated in a promising preliminary work [46].

\section{Acknowledgements}

Agence Nationale de la Recherche et de la Technologie is gratefully acknowledged for having granted this study (Cifre $\mathrm{N}^{\circ}$ 2015-0424).

a)

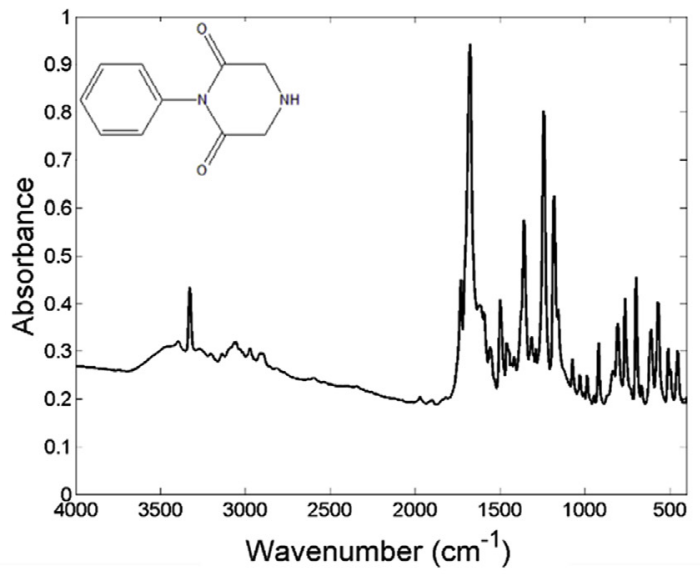

b)

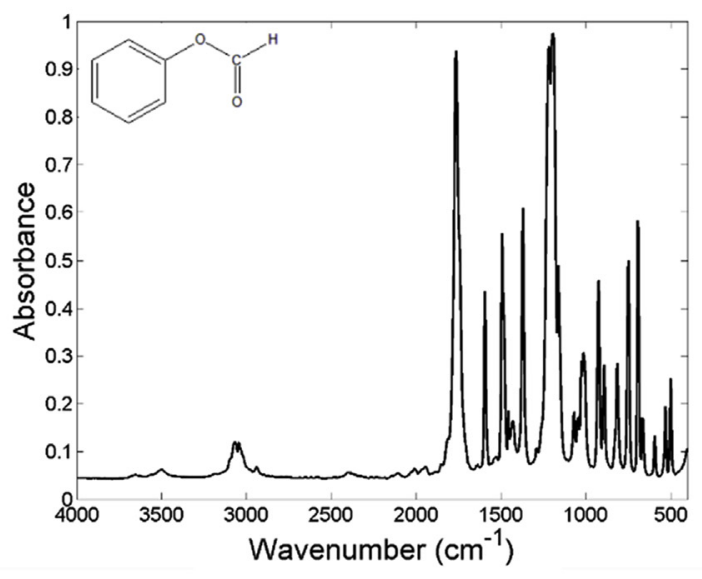

c)

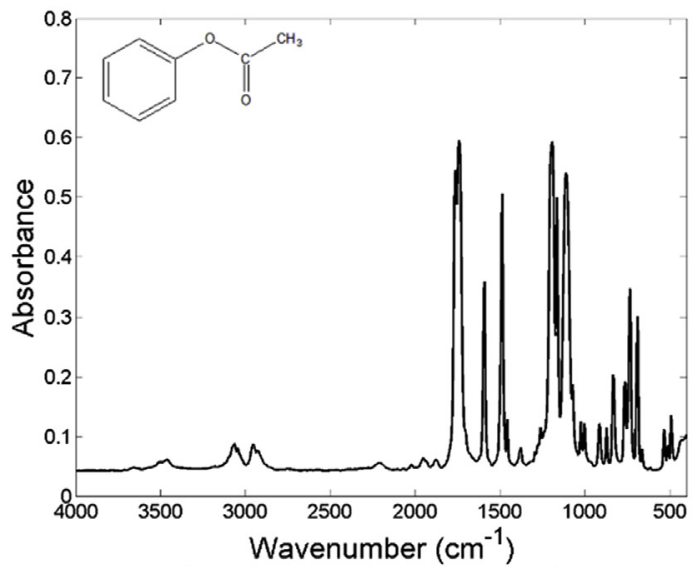

\section{APPENDIX 1}

Some of the characteristic absorptions reported in Table 2 were checked from spectra performed on model compounds (see Fig. 14):

- Phenyl acetate (CAS 122-79-2 - ref 30311-1 ML from Sigma Aldrich)

- Phenyl formate (CAS 1864-94-4 - ref 06556-5 ML from Sigma Aldrich)

- 1-Phenyl-2,6-Piperazinedione (ref PH007876-25 MG from Sigma Aldrich)
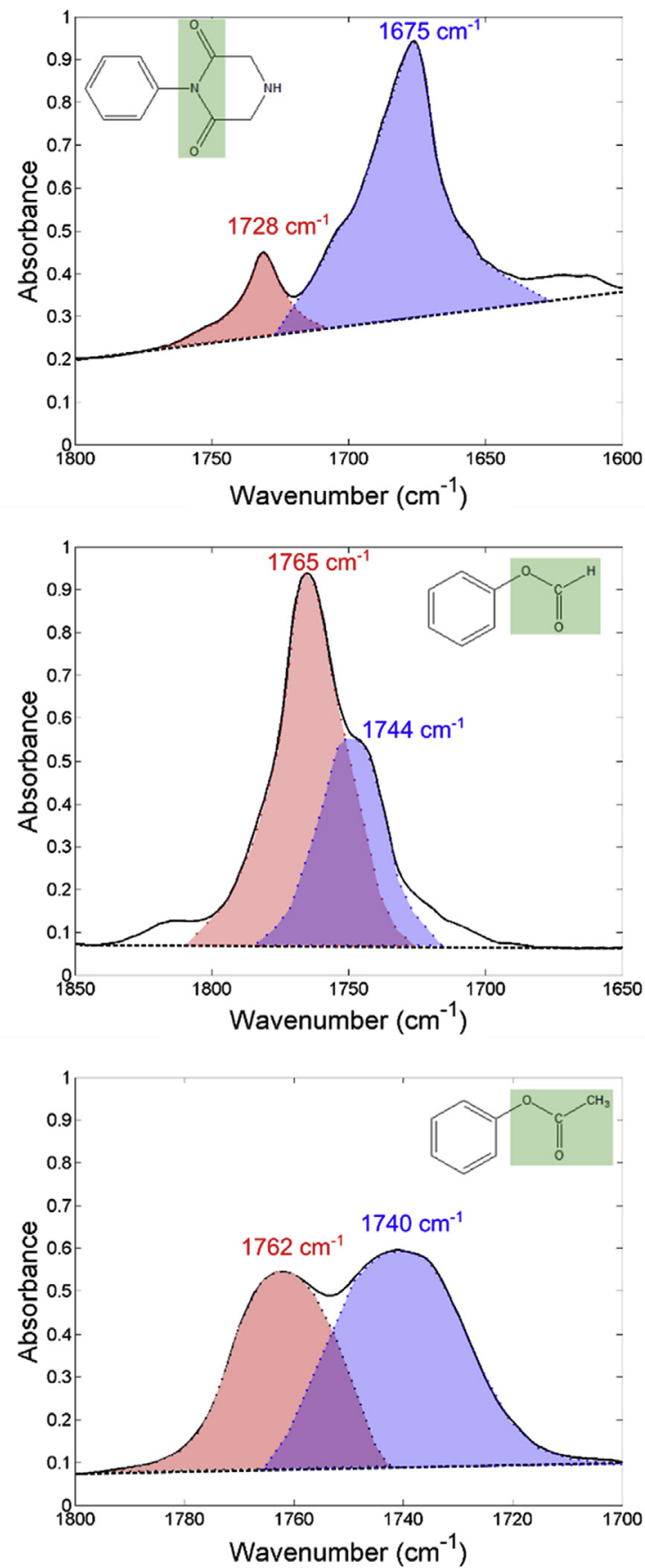

Fig. 14. FTIR spectra of model compounds: Imide (a), phenyl formate (b) and phenyl acetate (c). 


\section{APPENDIX 2}

The issue of the Bond dissociation Energy values used for discussing our mechanisms is not trivial:

- Firstly, values are given for model compounds matching more or less the reactive groups presents in epoxies.

- Secondly, they are usually given at $298 \mathrm{~K}$ and there is no simple maneer to extrapolate them in the ageing conditions under study.

- Thirdly, there are conformational effects in networks which can change the BDE value compared to simple molecules.

- Last, there is a certain scattering due to the multiple origin of values.

For example:

- For C-H in triethylamine, the CRC Handbook reports five values equal to $355.6,381,379.5,372.4$ and 381.6 [47] which is well in line (apart one value) with Table 3.

- For C-H in $\alpha$ position of alcohol, situation is more intricate: the CRC Handbook reports four values scattered from 373.6 to $390 \mathrm{~kJ} \mathrm{~mol}^{-1}$ meanwhile a significantly higher value (395 kJ mol${ }^{-1}$ ) can be found in Ref. [48].

- For anisole (or better phenetole), data are particulary hard to find. The CRC Handbook does not feature their values. We only noted that $\mathrm{C}-\mathrm{H}$ ethers at viciny of ethers are relatively oxidizable (ref [34] reports for example a $370 \mathrm{~kJ} \mathrm{~mol}^{-1}$ for isopropyl phenyl ether).

To conclude:

- We chose data coming from the same monograph ("Oxidation and Antioxidants in Organic Chemistry and Biology" [35-37]) because primary references involve the same main author (E. Denisov) so that we expect the experiments were done in reproducible conditions.

- We stress on the fact that those thermochemical data must be refined in the future by DFT calculations taking into account the electroattractive and hindrance effects and any other difference between model systems and cured networks in their ageing conditions.

- At last, for example in the case of the $\mathrm{C}$-H position in $\alpha$-position of ethers, the comparison for example with oxidation of DGEBA (monomer) or PKHJ monomer helped us to choose the most reactive sites in DGEBA-DDS.

\section{References}

[1] S. Terekhina, M. Mille, B. Fayolle, X. Colin, Oxidation induced changes in viscoelastic properties of a thermostable epoxy matrix, Polym. Sci. 55 (2013) 614-624. https://doi.org/10.1134/S0965545X13090058.

[2] E. Ernault, E. Richaud, B. Fayolle, Thermal-oxidation of epoxy/amine followed by glass transition temperature changes, Polym. Degrad. Stabil. 138 (2017) 82-90. https://doi.org/10.1016/j.polymdegradstab.2017.02.013.

[3] X. Buch, M.E.R. Shanahan, Thermal and thermo-oxidative ageing of an epoxy adhesive, Polym. Degrad. Stabil. 68 (2000) 403-411. https://doi.org/10.1016/ S0141-3910(00)00028-8.

[4] N.H. Giron, M.C. Celina, High temperature polymer degradation: rapid IR flowthrough method for volatile quantification, Polym. Degrad. Stabil. 145 (2017) 93-101. https://doi.org/10.1016/j.polymdegradstab.2017.05.013.

[5] X. Colin, A. Mavel, C. Marais, J. Verdu. Interaction between cracking and oxidation in organic matrix composites, J. Compos. Mater. 39 (2005) 1371-1389. https://doi.org/10.1177/0021998305050430.

[6] B.J. Anderson, Thermal stability of high temperature epoxy adhesives by thermogravimetric and adhesive strength measurements, Polym. Degrad. Stabil. 96 (2011) 1874-1881. https://doi.org/10.1016/j.polymdegradstab. 2011.07.010.
[7] J. Delozanne, N. Desgardin, M. Coulaud, N. Cuvillier, E. Richaud. Failure of epoxies bonded assemblies: comparison of thermal and humid ageing. J. Adhes. In Press. doi.org/10.1080/00218464.2018.1547198.

[8] T. Kamon, H. Furukawa, Curing mechanisms and mechanical properties of cured epoxy resins, in: K. Dušek (Ed.), Epoxy Resins and Composites IV, vol. 80, 1986, pp. 173-202. Advances in Polymer Science.

[9] E. Ernault, E. Richaud, B. Fayolle, Thermal oxidation of epoxies: influence of diamine hardener, Polym. Degrad. Stabil. 134 (2016) 76-86. https://doi.org/ 10.1016/j.polymdegradstab.2016.09.030.

[10] Y. Zahra, F. Djouani, B. Fayolle, M. Kuntz, J. Verdu, Thermo-oxidative aging of epoxy coating systems, Prog. Org. Coating 77 (2014) 380-387. https://doi.org/ 10.1016/j.porgcoat.2013.10.011.

[11] C. Galant, B. Fayolle, M. Kuntz, J. Verdu, Thermal and radio-oxidation of epoxy coatings, Prog. Org. Coating 69 (2010) 322-329. https://doi.org/10.1016/j. porgcoat.2010.07.005.

[12] S. Cukierman, J.-L. Halary, L. Monnerie, Molecular analysis of the viscoelastic properties of epoxy networks as deduced from the study of model systems, J. Non-Cryst. Solids 131-133 (1991) 898-905. https://doi.org/10.1016/00223093(91)90700-G.

[13] V. Bellenger, J. Verdu, Effect of structure on glass transition temperature of amine crosslinked epoxies, J. Polym. Sci. B Polym. Phys. 25 (1987) 1219-1234. https://doi.org/10.1002/polb.1987.090250604.

14] P. Musto, G Ragosta, P. Russo, L Mascia, Thermal-Oxidative degradation of epoxy and epoxy bismaleimide networks: kinetics and mechanism, Macromol. Chem. Phys. 202 (2001) 3445-3458. https://doi.org/10.1002/15213935(20011201)202:18<3445::AID-MACP3445>3.0.CO;2-N.

[15] P. Musto, Two-dimensional FTIR spectroscopy studies on the thermaloxidative degradation of epoxy and Epoxy-Bis(maleimide) networks, Macromolecules 36 (2003) 3210-3221, https://doi.org/10.1021/ma0214815.

16] S.V. Levchik, G. Camino, M.P. Luda, L. Costa, B. Costes, Y. Henry, G. Muller, E. Morel, Mechanistic study of thermal behaviour and combustion performance of epoxy resins. II. TGDDM/DDS system, Polym. Degrad. Stabil. 48 (1995) 359-370. https://doi.org/10.1016/0141-3910(95)00084-Y.

[17] P. Musto, M. Abbate, M. Pannico, G. Scarinzi, G. Ragosta, Improving the photooxidative stability of epoxy resins by use of functional POSS additives: a spectroscopic, mechanical and morphological study, Polymer 53 (2012) 5016-5036. https://doi.org/10.1016/j.polymer.2012.08.063.

[18] V. Bellenger, J. Verdu, Structure-photooxidative stability relationship of amine-crosslinked epoxies, Polym. Photochem. 5 (1984) 295-311. https://doi org/10.1016/0144-2880(84)90039-3.

[19] J. Decelle, N. Huet, V. Bellenger, Oxidation induced shrinkage for thermally aged epoxy networks, Polym. Degrad. Stabil. 81 (2003) 239-248. https://doi. org/10.1016/S0141-3910(03)00094-6.

20] X. Colin, C. Marais, J. Verdu, Kinetic modelling and simulation of gravimetric curves: application to the oxidation of bismaleimide and epoxy resins, Polym. Degrad. Stabil. 78 (2002) 545-553. https://doi.org/10.1016/S0141-3910(02) 00230-6.

[21] E. Ernault, J. Dirrenberger, E. Richaud, B. Fayolle, Prediction of stress induced by heterogeneous oxidation: case of epoxy/amine networks, Polym. Degrad. Stabil. 162 (2019) 112-121. https://doi.org/10.1016/j.polymdegradstab.2019 02.019.

[22] A. Quintana, M.C. Celina, Overview of DLO modeling and approaches to predict heterogeneous oxidative polymer degradation, Polym. Degrad. Stabil. 149 (2018) 173-191. https://doi.org/10.1016/j.polymdegradstab.2017.11.014.

[23] J. Lacoste, D. Vaillant, D.J. Carlsson, Gamma-, photo-, and thermally-initiated oxidation of isotactic polypropylene, J. Polym. Sci.: Polym. Chem. 31 (1993) 715-722. https://doi.org/10.1002/pola.1993.080310316.

[24] https://www.sigmaaldrich.com/catalog/product/aldrich/241989? lang=fr\&region $=\mathrm{FR}$

[25] http://www.spectroscopyonline.com/alcohols-rest-story.

[26] A. Rivaton, L. Moreau, J.-L. Gardette, Photo-oxidation of phenoxy resins at long and short wavelengths-II. Mechanisms of formation of photoproducts, Polym. Degrad. Stabil. 58 (1997) 333-339. https://doi.org/10.1016/S01413910(97)00088-8.

[27] A. Rivaton, B. Mailhot, J. Soulestin, H. Varghese, J.L. Gardette, Comparison of the photochemical and thermal degradation of bisphenol-A polycarbonate and trimethylcyclohexane-polycarbonate, Polym. Degrad. Stabil. 75 (2002) 17-33. https://doi.org/10.1016/S0141-3910(01)00201-4.

[28] B. Mailhot, S. Morlat-Thérias, M. Ouahioune, J.-L. Gardette, Study of the degradation of an epoxy/amine resin, 1, Macromol. Chem. Phys. 206 (2005) 575-584. https://doi.org/10.1002/macp.200400395.

[29] M. Gardette, A. Perthue, J.-L. Gardette, T. Janecska, E. Földes, B. Pukánszky, S. Therias, Photo- and thermal-oxidation of polyethylene: comparison of mechanisms and influence of unsaturation content, Polym. Degrad. Stabil. 98 (2013) 2383-2390. https://doi.org/10.1016/j.polymdegradstab.2013.07.017.

[30] C. Galant, B. Fayolle, M. Kuntz, J. Verdu, Thermal and radio-oxidation of epoxy coatings, Prog. Org. Coating 69 (2010) 322-329. https://doi.org/10.1016/j. porgcoat.2010.07.005.

31] E.T. Denisov, I.B. Afanas'ev, Oxidation and Antioxidants in Organic Chemistry and Biology, Taylor \& Francis Group, 2005. Chap 7. Oxidation of Alcohols and Ethers.

[32] J. Lemaire, R. Arnaud, J.-L. Gardette, Low temperature thermo-oxidation of thermoplastics in the solid state, Polym. Degrad. Stabil. 33 (1991) 277-294. https://doi.org/10.1016/0141-3910(91)90021-I.

[33] E. Richaud, O. Okamba Diogo, B. Fayolle, J. Verdu, J. Guilment, F. Fernagut 
Review: auto-oxidation of aliphatic polyamides, Polym. Degrad. Stabil. 98 (2013) 1929-1939. https://doi.org/10.1016/j.polymdegradstab.2013.04.012.

[34] S. Korcek, J.H.B. Chenier, J.A. Howard, K.U. Ingold, Absolute rate constants for hydrocarbon autoxidation. XXI. Activation Energies for propagation and the correlation of propagation rate constants with carbon-hydrogen Bond strengths, Rev. Can. Chim. 50 (1972) 2285-2297. https://doi.org/10.1139/v72 365.

[35] E.T. Denisov, I.B. Afanas'ev, Oxidation and Antioxidants in Organic Chemistry and Biology, Taylor \& Francis Group, 2005. Chap 7. Oxidation of Alcohols and Ethers. Table 7.1.

[36] E.T. Denisov, I.B. Afanas'ev, Oxidation and Antioxidants in Organic Chemistry and Biology, Taylor \& Francis Group, 2005. Chap 7. Oxidation of Alcohols and Ethers. Table 7.11.

[37] E.T. Denisov, I.B. Afanas'ev, Oxidation and Antioxidants in Organic Chemistry and Biology, Taylor \& Francis Group, 2005. Chap 9. Oxidation of Amines, Amides, and Esters. Table 9.1.

[38] E. Richaud, B. Fayolle, J. Verdu, J. Rychlý, Co-oxidation kinetic model for the thermal oxidation of polyethylene-unsaturated substrate systems, Polym. Degrad. Stabil. 98 (2013) 1081-1088. https://doi.org/10.1016/j. polymdegradstab.2013.01.008.

[39] E.T. Denisov, I.B. Afanas'ev, Oxidation and Antioxidants in Organic Chemistry and Biology, Taylor \& Francis Group, 2005. Chap. 9. Oxidation of Amines, Amides, and Esters. Table 9.2.

[40] E.T. Denisov, I.B. Afanas'ev, Oxidation and Antioxidants in Organic Chemistry and Biology, Taylor \& Francis Group, 2005. Chain Mechanism of Liquid-Phase Oxidation of Hydrocarbons.Table 2.1.
[41] E.T. Denisov, I.B. Afanas'ev, Oxidation and Antioxidants in Organic Chemistry and Biology, Taylor \& Francis Group, 2005. Chap 7. Oxidation of Alcohols and Ethers. Table 7.2

[42] V.J. Eichler, J. Mleziva, Studium der Reaktivität von aromatischen Diaminen mit Epoxidharzen, Angew. Makromol. Chem. 19 (1971) 31-55. https://doi. org/10.1002/apmc.1971.050190103.

[43] M.F. Mustafa, W.D. Cook, T.L. Schiller, H.M. Siddiqi, Curing behavior and thermal properties of TGDDM copolymerized with a new pyridine-containing diamine and with DDM or DDS, Thermochim. Acta 575 (2014) 21-28. https:// doi.org/10.1016/j.tca.2013.09.018.

[44] D. Bertin, M. Leblanc, S.R.A. Marque, D. Siri, Polypropylene degradation: theoretical and experimental investigations, Polym. Degrad. Stabil. 95 (2010) 782-791. https://doi.org/10.1016/j.polymdegradstab.2010.02.006.

[45] D. Bertin, S. Grimaldi, M. Leblanc, S.R.A. Marque, D. Siri, P. Tordo, A DFT study of the hydrogen atom abstraction from 2,4,6-trimethylheptane: a model of peroxidic degradation for syndio polypropylene, J. Mol. Struct. (Theochem) 811 (2007) 255-266. https://doi.org/10.1016/j.theochem.2007.03.008.

[46] J. Delozanne, Durabilité des époxys - Application au collage structural aéronautique, PhD thesis, Arts et Métiers ParisTech, 2018.

[47] Yu-Ran Luo, Handbook of Bond Dissociation Energies in Organic Compounds || Tabulated BDEs of C-H Bonds, 2002, https://doi.org/10.1201/ 9781420039863.ch3.

[48] V.B. Oyeyemi, J.A. Keith, E.A. Carter, Trends in Bond dissociation Energies of alcohols and aldehydes computed with multireference averaged coupled-pair functional theory, J. Phys. Chem. A 118 (2014) 3039-3050. https://doi.org/10. 1021/jp501636r. 